\title{
1 History of Wildlife Toxicology and the Interpretation of Contaminant Concentrations in Tissues
}

\author{
Barnett A. Rattner \\ Anton M. Scheuhammer \\ John E. Elliott
}

\section{CONTENTS}

1.1 Introduction 9

1.2 The Beginnings of Wildlife Toxicology ........................................................................... 10

1.3 Synthetic Pesticides and Poisoning of Wildlife ................................................................. 11

1.4 “Silent Spring” and Population Level Effects .................................................................. 12

1.5 Advances in Measurement Endpoints of Contaminant Exposure ....................................... 14

1.6 Interpreting Exposure Using New Molecular and Modeling Techniques ........................... 16

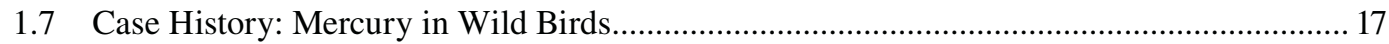

1.8 Case History: Dioxins and PCBs in Wild Birds ............................................................. 21

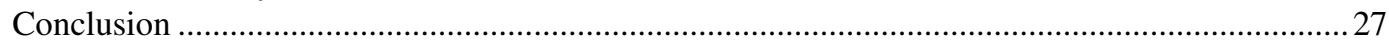

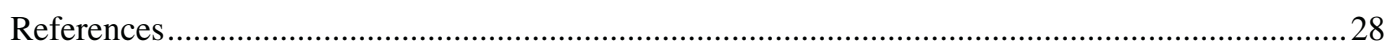

\subsection{INTRODUCTION}

The detection and interpretation of contaminants in tissues of wildlife belongs to the field of toxicology, a scientific discipline with a long, intriguing, and illustrious history (reviewed by Hayes 1991, Gallo 2001, Gilbert and Hayes 2006, Wax 2006). We review its history briefly, to provide a context for understanding the use of tissue residues in toxicology, and to explain how their use has developed over time. Because so much work has been conducted on mercury, and dioxins and polychlorinated biphenyls (PCBs), separate case histories are included that describe the evolution of the use of tissue concentrations to assess exposure and effects of these two groups of contaminants in wildlife.

The roots of toxicology date back to early man, who used plant and animal extracts as poisons for hunting and warfare. The Ebers papyrus (Egypt $~ 1550$ BC) contains formulations for hemlock, aconite (arrow poison), opium, and various metals used as poisons. Hippocrates ( 400 BC) is sometimes credited with proposing the treatment of poisoning by decreasing absorption and using antidotes (Lane and Borzelleca 2007). Chanakya (350-283 BC), Indian advisor of the Maurya Emperor Chandragupta (340-293 BC), urged the use of food tasters as a precaution against poisoning, and 
the Roman emperor Claudius may have even been poisoned by his taster Halotus in 54 AD. Moses ben Maimon (1135-1204), author of a treatise on poisoning, noted that dairy products could delay absorption of some poisons. Paracelsus (1493-1541) shaped the field of toxicology with his corollaries that experimentation is essential to examining the response, that therapeutic properties should be distinguished from toxic properties, that chemicals have specific modes of action, and that the dose makes the poison. The art of concocting and using poisons reached its "zenith" during the Italian Renaissance, eventually culminating in its commercialization by Catherine Deshayes (a.k.a., La Voisine, 1640-1680) in France.

One of the first to suggest a chemical method for the detection of a poison in modern times was Herman Boerhaave (1668-1738), a physician and botanist, who, according to Jurgen Thorwald (The Century of the Detective), placed the suspected poison on red-hot coals, and tested for odors. The Spanish physician Orfila (1787-1853) served in the French court, and was the first toxicologist to systematically use autopsy and chemical analysis to prove poisoning. He has been credited with developing and refining techniques to detect arsenic poisoning. Other historic accounts include extraction of alkaloids from postmortem specimens (Jean Servais Stas 1851 ) as evidence in a nicotine poisoning case (Levine 2003). The chemical analysis of organs and tissues became the basis for establishing poisoning. Much of the early history of toxicology addressed whether someone had been poisoned and how to treat poisoning.

\subsection{THE BEGINNINGS OF WILDLIFE TOXICOLOGY}

Wildlife toxicology has generally dealt with environmental contamination and the unintentional poisoning of amphibians, reptiles, birds, and mammals (Rattner 2009). Concern over poisoning of wildlife began in the late nineteenth century, and initially focused more on identifying environmental problems than determining contaminant concentrations in tissues. Reports of pheasant (Phasianus colchicus) and waterfowl mortality related to ingestion of spent lead shot appeared in the popular literature (Calvert 1876, Grinell 1894). Once recognized, it was considered a common occurrence in waterfowl (Phillips and Lincoln 1930). Wetmore (1919) described postmortem signs of intoxication in waterfowl that contained shot in the gizzard and other portions of the digestive tract. Poisoning of waterfowl from lead mining wastes dumped into the Spring River in Kansas was described in 1923 (Phillips and Lincoln 1930). A report of arsenic-related mortality of fallow deer (Dama dama) near factories processing metal ores in Freiberg, Germany, made its way into the popular press in 1887 (Newman 1979). Controlled exposure studies with mercury, strychnine, and arsenic were conducted in domestic and wild fowl (Gallagher 1918, Whitehead 1934), including measurement of arsenic in tissues of dosed chickens (Gallus gallus) (Whitehead 1934). Alkali poisoning of thousands of eared grebes (Podiceps nigricollis) and shovelers (Anas clypeata) was documented in California in 1891 (Fisher 1893). Similar cases were subsequently described in many locations in the western United States, and alkali poisoning was even experimentally duplicated by Wetmore using captive birds, which were administered chlorides of calcium and magnesium (Phillips and Lincoln 1930). The hazard of ingested phosphorus from military munitions by waterfowl and swans was first recognized in 1923, and emerged as a problem on several occasions decades later (Phillips and Lincoln 1930). With the expansion of oil production and its use for marine propulsion after World War I, oiling of waterbirds and numerous die-offs occurred along the coast of the United States (over 35 incidents documented in Phillips and Lincoln 1930). In the aforementioned mortality incidents (i.e., lead shot, arsenic, alkali, phosphorus, and oil), the source and the presence of the toxicant were usually readily apparent (e.g., recovery of ingested shot, alkali salts or oil in or on birds).

Qualitative and quantitative determination of presence of lead in stomach and caeca of waterfowl was described as early as 1919 (Wetmore 1919, Magath 1931). Traces of arsenic were reported in the liver of dead deer following application of calcium arsenate for forest insect control in 1926 (Danckwortt and Pfau cited by Keith 1996). In the detailed description of poisoning of nontarget 
wildlife by thallium baits used to control ground squirrels, Linsdale (1931) mentioned the use of qualitative spectroscopic methods to detect thallium in tissues of dead geese, and quantitative methods to determine concentrations in edible tissues. Before 1940, the presence or actual concentrations principally served as evidence of exposure. Quantitative methods were used in analyzing lead-poisoned geese (Branta canadensis) in the early 1940s, and "some correlation" between the number of shot found in the gizzard with lead content of the liver and kidney (but not leg bone) was suggested (Adler 1944).

Environmental contaminant studies with captive waterfowl began at the Patuxent Research Refuge in the late 1940s. Through controlled exposure studies with captive birds, evidence of adverse effects (histopathological lesions, impaired reproduction, and lethality) on individuals began to be generated. In toxicity studies of white phosphorus used in military munitions, Coburn and coworkers (1950) found statistically significant changes in concentrations of elemental phosphorus in heart, liver, and kidney of mallards (Anas platyrhynchos) and black ducks (Anas rubripes) that were dosed with various quantities of white phosphorus. These data were then used to interpret phosphorus concentration in tissues of redhead ducks (Aythya americana) collected from northern Chesapeake Bay, which led to the conclusion that "it appears probable" that the birds had been killed from ingestion of elemental phosphorus (Coburn et al. 1950). In order to interpret quantities of lead that produce toxic signs in waterfowl, mallards were dosed with lead nitrate (soluble and readily absorbable form of lead) for several weeks (Coburn et al. 1951). Anemia, emaciation, and a number of pathological lesions were consistently noted, and lead concentration in bone and liver was 7 and 40 times greater than that found in control birds. The critical lead intake level was suggested to be between 6 and $8 \mathrm{mg} / \mathrm{kg}$ body weight/day, and it was stated that bone, liver, or soft tissues could be used to chemically verify lead poisoning in field samples.

\subsection{SYNTHETIC PESTICIDES AND POISONING OF WILDLIFE}

By the 1930s, a total of about 30 pesticides were in use in the United Kingdom, United States and elsewhere, including plant derivatives (e.g., pyrethrum and nicotine), inorganic compounds (e.g., calcium arsenate and lead), mercurial fungicides, and the synthetic weed killer dinitro-ortho cresol (Sheail 1985). Aerial application of pesticides became a common practice in the 1930s, and potential adverse effects of pesticides to wildlife were acknowledged at the Third North American Wildlife Conference (Strong 1938).

The discovery of the insecticidal properties of dichlorodiphenyltrichloroethane (DDT) in 1939, the development, production, and use of other organochlorine (e.g., hexachlorocyclohexane), organophosphorus pesticides (e.g., schradan), and rodenticides (e.g., Compound 1080), increased dramatically during and after World War II (Hayes 1991). Concerns about potential damaging effects of DDT on wildlife appeared in The Atlantic Monthly (Wigglesworth 1945), which prompted experimental studies. Field studies of DDT effects on wildlife were undertaken in Maryland, Pennsylvania, and Texas, and reduced numbers of some avian species and dead birds were noted at application concentrations of 4.4 and 5 pounds per acre (Hotchkiss and Pough 1946, George and Stickel 1949, Robbins and Stewart 1949). Parathion poisoning of geese attributed to spray drift was also reported at this time (Livingston 1952). In the United Kingdom, large numbers of wildlife poisonings (e.g., passerines, game birds, mammals) occurred in the early and mid-1950s related to the use of aldrin and dieldrin as seed dressings, and application of schradan for control of aphids (Sheail 1985). Many other organochlorine insecticides (e.g., chlordane, heptachlor, and toxaphene) came into use in agricultural and forest settings in the 1950s, and wildlife mortality was noted (Peterle 1991).

Reports of wildlife mortality from pesticide use were controversial, pitting scientists associated with agriculture and chemical companies against environmental scientists. Biologists relied on tissue analyses not just to understand environmental hazards associated with pesticides, but also to provide more definitive evidence of exposure and even adverse effect. This controversy also served 
as an impetus to conduct controlled studies, which often relied on tissue concentrations as a measurement endpoint.

Data on concentrations of organic pesticides in tissues of wildlife began to appear in the early 1950s. Analysis of liver tissue from dead and intoxicated pheasants collected at pesticide-treated orchards revealed elevated concentrations of DDT (up to $326 \mu \mathrm{g} / \mathrm{g}$ ), while parathion was detected in only a few birds (up to $5 \mu \mathrm{g} / \mathrm{g}$ ) (Barnett 1950). Chronic dietary DDT and parathion feeding trials in pheasants demonstrated that the kinetics of the two pesticides were quite different (Barnett 1950). Substantial quantities of DDT were detected in fat (up to $8104 \mu \mathrm{g} / \mathrm{g}$ ) and liver (up to $94 \mu \mathrm{g} / \mathrm{g}$ ), but usually only trace amounts of parathion were found in liver. In a songbird study evaluating DDT (applied at 3 pounds per acre), Mitchell et al. (1953) found that whole body DDT concentrations in dead nestling songbirds were variable (up to $77 \mu \mathrm{g} / \mathrm{g}$ ) and tended to be greater in dead nestlings in the sprayed area compared to the reference site. However, the overall songbird population was not affected (Mitchell et al. 1953). During this period, aldrin, dieldrin, and heptachlor were detected in tissues of dead birds and mammals following their field application (Post 1952, Clawson and Baker 1959, Scott et al. 1959, Rosene 1965). As aptly pointed out by Keith (1996), during this era investigators documented pesticide exposure in tissues of dead birds, but were often hesitant to conclude that the cause of death was pesticide-related.

Acute and chronic exposure studies were conducted using captive game birds that described signs of intoxication, lethality, and accumulation of residues of organochlorine pesticides in tissues (Dahlen and Haugen 1954, DeWitt 1955, 1956, DeWitt et al. 1955). The hazard of toxic chemicals to wildlife was frequently investigated using a combined laboratory-field approach (viz., determining the tissue concentrations of the compound and/or metabolites present in intoxicated or dead wild animals, and then comparing those values to concentrations in experimentally dosed animals exhibiting toxicological signs or effects) (Peakall 1992, Keith 1996). This approach worked well for organochlorine contaminants that readily bioaccumulated in tissues and exerted their lethal effects through neurotoxic mechanisms. For example, dietary feeding studies with captive quail and pheasants demonstrated that the concentrations of DDT in breast muscle were related to the severity of intoxication, with $34 \mu \mathrm{g} / \mathrm{g}$ in adult bobwhite (Colinus virginianus) and $22 \mu \mathrm{g} / \mathrm{g}$ in adult pheasants being associated with death (DeWitt et al. 1955). Barker (1958) reported brain concentrations of DDT and DDE (dichlorodiphenyldichloroethane) in robins (Turdus migratorius) and other passerines that succumbed following DDT application for Dutch elm disease. Based on this field study it was concluded that "the brain, being a suspected site of action, was considered to be best as an indicator of toxicity," with greater than $60 \mu \mathrm{g} / \mathrm{g}$ indicative of death in robins (Barker 1958). Other investigators made similar conclusions on the toxic concentration of DDT in brain tissue $(>50 \mu \mathrm{g} / \mathrm{g})$ in several species of birds, and extended findings by considering the sum of metabolites (Bernard 1963, Wurster et al. 1965, Stickel et al. 1966). This approach was used for many organochlorine compounds, including chlordane, heptachlor, dieldrin, and Aroclor 1254 (DeWitt et al. 1960, Stickel et al. 1969, 1984, and reviewed by Hoffman et al. 1996, Peakall 1996, Wiemeyer 1996). To improve diagnostic capabilities for free-ranging wildlife, the effects of body condition, lipid reserves, cessation of feeding, cold, and other stressors on tissue distribution and mobilization of organochlorines were examined in both controlled exposure and field studies (Harvey 1967, Stickel et al. 1970, Van Velzen et al. 1972, Heinz and Johnson 1981).

\section{4 "SILENT SPRING" AND POPULATION LEVEL EFFECTS}

With the publication of Rachel Carson's Silent Spring (1962), issues such as adverse effects of pesticides on nontarget organisms, ecological imbalances, chemical persistence, pesticide resistance, and human safety were publicized and debated not only among scientists, but also in all sectors of society. Eventually, some pesticides and environmental issues were addressed through testimony before government entities and courtroom litigation. This environmental movement sparked new legislation (e.g., in the United States, Resource Conservation and Recovery Act in 1965, National Environmental 
Policy Act in 1970, and Toxic Substances Control Act in 1976; reviewed by Fairbrother 2009) and the establishment of distinct governmental agencies to deal with environmental pollution (e.g., U.S. Environmental Protection Agency in 1970). Research programs related to pesticides and industrial chemicals expanded in North America, Europe, and elsewhere. In the United Kingdom, Monks Wood Experimental Station was established to investigate effects of chemicals on animals and their supporting habitat. Chemical screening programs were initiated to examine toxicity, repellency and potential hazard of chemicals to birds and mammals (Heath et al. 1972, Schafer et al. 1983), and longterm environmental contaminant monitoring programs were established.

Population declines observed in many species of fish-eating and raptorial birds were of great concern to biologists. Following the discovery of an increased frequency of broken peregrine falcon (Falco peregrinus) eggs in England, Moore and Ratcliffe (1962) and many other investigators (reviewed in Sheail 1985 and Keith 1996) detected organochlorine pesticide residues (e.g., DDE, dieldrin, and lindane) in eggs. In a classic paper, Ratcliffe (1967) reported that weights of raptor eggshells fell markedly and rapidly after DDT use was instituted, and Hickey and Anderson (1968) used correlation analysis to demonstrate that shell thickness was inversely related to the concentration of DDE in eggs. Controlled exposure studies followed that proved DDE caused eggshell thinning and impaired reproduction (Heath et al. 1969). Similar relationships have been demonstrated in a number of predatory avian species (Hickey and Anderson 1968, Blus et al. 1972, Blus 1996), although some species are considerably more sensitive (e.g., brown pelican, Pelecanus occidentalis) than others. Concerns over the effects of moisture loss related to incubation stage, particularly in addled eggs, resulted in the development of concentration correction factors (Stickel et al. 1973). Adverse effects of organochlorine pesticides were also described in wild mammals, most notably bats (reviewed in Clark and Shore 2001), and the first reports of organochlorine contaminants and mercury appeared in marine mammals in the 1960s (reviewed in O'Shea and Tanabe 2003). The use of tissue residues has evolved from merely explaining the cause of local wildlife die-offs to its use in the investigation of the status of wildlife populations, and in some cases the possible fate of species.

Advances in chemical analysis and instrumentation enhanced detection capabilities and revealed some unsuspected problems. In 1966, Swedish scientist Soren Jensen reported several unknown peaks in a gas chromatogram that interfered with the quantification of DDT in environmental samples (Jensen 1966). These unknown peaks were subsequently identified as PCBs, which raised the possibility that previously reported DDT and metabolite values may have been falsely elevated by these interfering peaks. It was quickly recognized that PCBs were present in biota on a global scale, with perhaps the highest concentrations in fish-eating birds (up to 14,000 $\mu \mathrm{g} / \mathrm{g}$ ) (Risebrough et al. 1968, Wasserman et al. 1979). Quantification of these complex mixtures was based in part on matching chlorinated biphenyl patterns to the commercial Aroclor formulations, classified on the percentage of chlorination of the biphenyl. In the environment, these complex mixtures changed substantially due to natural weathering and biological processes, and Aroclor pattern recognition techniques were used to quantify total PCB concentrations in free-ranging wildlife. Toxicity studies of PCBs were undertaken in birds and mammals. It was realized that poor reproduction in ranch mink (Mustela vison) was due to the presence of PCBs in their food source, Great Lakes coho salmon (Oncorhynchus kistutch) (Aulerich and Ringer 1977). In the 1970s, studies focused on commercial mixtures (e.g., Aroclor 1254, Clophen A60), and concentration thresholds associated with lethality and embryotoxicity (e.g., <10 $\mu \mathrm{g} / \mathrm{g}$ in eggs; reviewed by Hoffman et al. 1996). Concentrations of PCBs in liver and whole bodies were found to be indicative of exposure, but of limited diagnostic value in explaining mortality events (i.e., extremely high concentrations of PCBs are necessary to evoke mortality in adult birds).

Studies in the 1960s indicating a possible link between contaminant exposure (mainly organochlorines) and reproductive dysfunction in Great Lakes colonial nesting waterbirds (Hickey et al. 1966, Keith 1966, Gilbertson 1974, 1975, Gilman et al. 1977) led to a long-term research and monitoring program (Peakall and Fox 1987) using herring gulls (Larus argentatis) as bioindicators. 
This herring gull monitoring program still continues today as an integral part of a multifacetted bi-national program to evaluate Great Lakes ecosystem health (Shear et al. 2003).

The toxicity of metals during this era focused primarily on mercury and lead. By the late 1950s, waterfowl poisoning by ingestion of spent lead shot, and effects on populations were further characterized (Bellrose 1959). Studies with captive Canada geese (Cook and Trainer 1966) and mallards (Locke et al. 1966, Barrett and Karstad 1971) dosed with lead shot reported concentrations of lead in liver and blood, associated pathological lesions, signs of intoxication, and death. However, in a lead study by Longcore and coworkers (1974) ranges indicative of exposure were proposed ( $>3 \mu \mathrm{g} / \mathrm{g}$ wet weight in brain, $6-20 \mu \mathrm{g} / \mathrm{g}$ in liver or kidney, and $10 \mu \mathrm{g} / \mathrm{g}$ in blood), that when combined with necropsy findings (presence of lead fragments in digestive tract), case history and histopathological lesions, could be used to make a definitive diagnosis of lead poisoning. In time and with the acquisition of additional data, these ranges became a more formalized criteria, including categories of lead exposure (e.g., background), and levels of injury or effect (e.g., subclinical, clinical, and severe poisoning) (Friend 1985, Franson 1996, Pain 1996).

\subsection{ADVANCES IN MEASUREMENT ENDPOINTS OF CONTAMINANT EXPOSURE}

By the 1970s, restrictions were placed on the use of some organochlorine compounds, including DDT and PCBs, although to some scientists the decision on DDT was misguised (Roberts et al. 2010). Controlled exposure studies in wild birds and mammals began to focus on sublethal biochemical, physiological, and behavioral effects of organic compounds and metals.

Use of organophosphorus and carbamate pesticides for farm crops, mosquito abatement, and for control of forest insect pests (e.g., spruce budworm in Canada described as "The Thirty Years' War," Burnett 1999) increased dramatically. Although these anticholinesterase pesticides had short environmental half-lives, they were not without adverse effects to birds and other nontarget organisms (Mineau 1991, Kendall and Lacher 1994, Grue et al. 1997). Because these compounds are rapidly metabolized, laboratory studies focused on enzymatic indicators (cholinesterase and other esterases) in blood and tissues of exposed birds (Bunyan et al. 1968a, 1968b, Ludke et al. 1975). Detection of organophosphate poisoning in wildlife quickly evolved to include the combination of inhibition of cholinesterase activity in brain tissue $(\sim 50 \%)$ along with the presence of organophosphorus or carbamate parent compounds or metabolites in tissues or ingesta (Hill and Fleming 1982). Many direct poisoning cases, and intriguing incidents involving secondary poisoning, are described in the peer-reviewed literature (Henny et al. 1985, Mineau et al. 1999). Refinements over time included the development of extensive libraries of reference values for unexposed animals and cholinesterase reactivation assays (Fairbrother et al. 1991). The combination of reduced cholinesterase activity and detection of residues or metabolites in tissues for diagnosis of poisoning has remained steadfast (Hill 2003).

Although a longstanding problem, major petroleum spills resulting in large bird kills (e.g., Torrey Canyon in 1967, Union Oil drilling platform in 1969, Arrow tanker in 1970) heightened public awareness and concern. From both an historical (Phillips and Lincoln 1930) and modern day perspective, evidence of exposure of wildlife following major oil spills is usually apparent by visual inspection and petroleum odor of the integument (feathers or fur) of suspect animals. In the 1960s and 1970s, numerous controlled exposure studies were undertaken that focused on characterizing the effects of crude petroleum oil and refined petroleum products on wildlife (Holmes 1984, Jessup and Leighton 1996). Despite the development of analytical methods (e.g., Gay et al. 1980), tissue concentrations and related measures (e.g., total resolved hydrocarbons; presence of aromatic, high molecular weight hydrocarbons and odd-numbered hydrocarbons; and ratios of pristine to $\mathrm{n}-\mathrm{C} 17$ and phytane to $\mathrm{n}-\mathrm{C} 18$; Hall and Coon 1988) are only occasionally measured in wildlife following oil spill events. In time it became recognized that (1) the composition of crude and refined petroleum varies considerably, (2) the chemical and physical properties of petroleum change through weathering and volatilization following a spill, (3) ingested petroleum compounds 
are often rapidly metabolized, and (4) there are substantial differences in toxicity following external exposure and ingestion of various crude or refined petroleum products (Jessup and Leighton 1996, Albers 2003). Accordingly, tissue concentrations of aliphatic and aromatic components of petroleum oil that are associated with adverse effects have not been developed. Instead, measurements are used to document exposure, most commonly for purposes of natural resource damage assessments following a spill event. However, confirmation of the presence of petroleum oil on the integument does not necessarily indicate that oil was the cause of death (Jessup and Leighton 1996). In the 1980s, enzyme-linked immunosorbent assays for detection of oil, and detailed fingerprinting for matching oil on exposed animals with its source were developed, and are now commonly used (Peters et al. 2005).

By the end of the 1980s, the use of lead shot for hunting waterfowl and coots was banned in the United States, and restrictions were placed on the use of lead fishing tackle in the United Kingdom due to the unintentional poisoning of mute swans (Cygnus olor) (Pattee and Pain 2003). Investigations on effects of heavy metals (e.g., lead, cadmium, and zinc) at industrial, mining, and hazardous waste sites examined exposure and responses at the individual and population levels of biological organization. Selenium became a significant environmental issue in the early 1980s when dramatic effects, including death and embryonic deformity of birds, were observed at the Kesterson National Wildlife Refuge in California (Ohlendorf and Hothem 1995, Ohlendorf 2003). In response to findings of selenosis and waterbird death at the Kesterson Reservoir, numerous field and feeding studies of birds were undertaken to establish toxicity thresholds. Using various statistical models (logit, probit, Weibull functions), much emphasis was placed on determining the toxicity of selenium in bird eggs. The probability of teratogenesis in black-necked stilts (Himantopus mexicanus) increased when selenium concentrations exceeded $37 \mu \mathrm{g} / \mathrm{g}$ dry weight (i.e., EC10, estimate of concentration affecting $10 \%$ of the population), while the EC10 for teratogenesis in mallards and in American avocets (Recurvirostra americana) was estimated to be 23 and $74 \mu \mathrm{g} / \mathrm{g}$, respectively (Skorupa 1998a, 1998b). The threshold for reduced egg hatchability, a more sensitive measure of selenosis, was estimated to be $6-7 \mu \mathrm{g} / \mathrm{g}$ in stilt eggs, but avocets were found to be considerably more tolerant with hatchability effects at $60 \mu \mathrm{g} / \mathrm{g}$. There has been considerable debate on the selenium threshold concentration for impaired hatchability in waterfowl, with an EC10 ranging from 12.5 to $16 \mu \mathrm{g} / \mathrm{g}$.

The development and use of biomarkers of contaminant exposure and adverse effect expanded dramatically in the 1990s (McCarthy and Shugart 1990, Huggett et al. 1992, Peakall and Shugart 1993). The impetus was multifold. Organic contaminant and elemental analysis of tissues was, and continues to be, highly quantitative but costly and time consuming. Some biochemical measurements were amenable to rapid screening of samples, and a few were rather specific for certain contaminants and linked to the mechanism of toxicity (e.g., $\delta$-aminolevunic acid dehydratase inhibition and protoporphyrin accumulation in blood of lead-poisoned birds and mammals). In some instances, rapid metabolism does not permit detection of parent compounds or metabolites in tissues, and thus enzymatic and other biochemical assays are utilized in place of tradition analytical methods (e.g., neurotoxic esterase activity for organophosphorus-induced delayed neuropathy caused by tri-o-tolyl phosphate and leptophos; Ecobichon 1996). It was quickly recognized that other biochemical measurements (e.g., changes in plasma transaminase and lactate dehydrogenase activities) were sensitive generalized responses that were precursors or indicators of cellular damage, although such measurements lack toxicant specificity. In time, other biomarkers (cytochrome P450, metallothionein, heat stress proteins, DNA damage, and measures of oxidative stress) were utilized as indicators of exposure and/or adverse effects in wildlife, and several exhibited doseresponse relationships. Endpoint measurements were characterized for sensitivity, specificity, variability, clarity of interpretation, validity, and applicability to field sampling (McCarthy and Shugart 1990, Huggett et al. 1992, Peakall and Shugart 1993). Although biochemical markers are of tremendous value in ecotoxicology, only a few have gained widespread acceptance for risk assessments and natural resource damage assessments. Often these endpoints are most valuable as ancillary measures used in combination with contaminant concentration and other endpoints. 


\subsection{INTERPRETING EXPOSURE USING NEW MOLECULAR AND MODELING TECHNIQUES}

On a grand scale, high prevalence of embryonic deformity was observed in some populations of colonial nesting fish-eating birds in the Great Lakes (Great Lakes Embryo Mortality, Edema, and Deformities Syndrome; Gilbertson et al. 1991). Such epidemic-like events and catastrophes including the Chernobyl nuclear reactor meltdown, and the Exxon Valdez and Gulf War oil spills, greatly expanded ecotoxicological research worldwide. Exposure studies with captive wild birds and mammals, in parallel with modeling efforts, were used to estimate no adverse effect level (NOAEL) and lowest observable adverse effect level (LOAEL) for PCBs in diets and drinking water (e.g., Heaton et al. 1995, U.S. EPA 1995, Forsyth 2001). Perhaps more germane to this text, the tissue concentrations of PCBs that correspond to the dietary NOAEL and LOAEL were also estimated (Heaton et al. 1995, Forsyth 2001). The realization of extreme toxicity of dioxin and dioxin-like coplanar PCB congeners in laboratory rodents (Poland and Knutson 1982), chicken eggs, and cell culture systems (Safe 1984, 1990) led to measurement (Kubiak et al. 1989) and toxicity testing (reviewed by Hoffman et al. 1996) of individual congeners in wildlife. The use of mammalian toxic equivalency factors to estimate dioxin equivalents of coplanar PCB congeners was applied to wild bird eggs. Potency estimates for dioxin-like PCB congeners (toxic equivalents, TEQs) were subsequently compiled (reviewed in Hoffman et al. 1996), and along with dioxins and dibenzofurans were eventually formalized at a World Health Organization workshop in 1997 (Van den Berg et al. 1998).

The use of nondestructive and minimally or noninvasive sampling techniques became more common in the 1990s. The rationale arose from the desire to use samples that did not entail the sacrifice of animals for ethical or scientific reasons (species status as threatened or endangered) and the sampling of animals repeatedly at a site where only a few individuals were found (Fossi and Leonzio 1994). Much of the analysis of such samples has focused on biochemical endpoints. Concentrations of organochlorine pesticides and metabolites, PCBs, and metals (lead, mercury, cadmium, and vanadium) in blood, milk, feathers, hair, and excreta are often correlated with levels found in historically used tissues (e.g., liver and kidney), and thus critical concentration values associated with harm were developed for some contaminants in these matrices (Fossi and Leonzio 1994).

Pesticide hazards to migratory species were highlighted by the death of some 20,000 Swainson's hawks (Buteo swainsoni) from monocrotophos poisoning during their winter migration to Argentina (Hooper et al. 2003). Monitoring and forensic studies documented anticoagulant rodenticide exposure and secondary poisoning in raptors (e.g., Stone et al. 1999, 2003), and restrictions were placed on the use of some of these compounds (US EPA 2008). Investigation of wildlife die-offs at industrial and mining sites continued (e.g., Hill and Henry 1996, Henny 2003), and in some instances metal concentration thresholds in tissues associated with toxicity were established (e.g., vanadium, Rattner et al. 2006). Studies of forest birds exposed to the organic-arsenical pesticide MSMA (monosodium methanearsonate) used for suppression of the mountain pine beetle in British Columbia revealed a significant hazard to woodpeckers (Picoides spp.), and findings led to the removal of MSMA from the marketplace (Morrissey et al. 2007, Albert et al. 2008). With reports of feminization of alligators (Alligator mississippiensis) in Lake Apopka, Florida (Guillette et al. 1994) and the publication of Our Stolen Future (Colborn et al. 1996), laboratory and field investigations were launched that focused on endocrine-disruptive effects of pollutants on wildlife. Despite extensive research, widespread effects of pollutants on endocrine function of free-ranging wildlife have been difficult to demonstrate; however, effects on the gonadal subsystem of wild fish seem to be pronounced (Jobling et al. 1998). Ecotoxicological research and monitoring of amphibians greatly expanded in response to worldwide declines of their populations, and the realization that some pesticides might be responsible for limb and other structural deformities (Sparling et al. 2000).

Emerging contaminant issues in the twenty-first century have included the global detection of perfluoroalkyl surfactants in wildlife (Giesy and Kannon 2001), and the dramatic increase in 
concentrations of polybrominated diphenyl ether (PBDE) flame retardants in eggs and tissues of birds (Norstrom et al. 2002). The population crash of Gyps vultures in the Indian subcontinent resulted in a remarkable forensic investigation documenting secondary poisoning (renal failure) of vultures that fed on carcasses of cattle that had been treated with the nonsteroidal anti-inflammatory drug diclofenac (Oaks et al. 2004). Old World vultures were found to be quite sensitive to diclofenac (LD50 of 0.1 to $0.2 \mathrm{mg} / \mathrm{kg}$ body weight), with concentrations in kidney and liver of affected birds being $<1 \mu \mathrm{g} / \mathrm{g}$ wet weight (Oaks et al. 2004, Shultz et al. 2004, Swan et al. 2006). This catastrophic event was the first time that a veterinary drug resulted in species endangerment. Notably, New World vultures do not seem to be sensitive to diclofenac (Rattner et al. 2008).

The use of stable isotopes to identify the environmental source of a metal is a recent development in the field of wildlife toxicology. In a study of California condors (Gymnogyps californianus), lead concentrations and stable isotope ratios demonstrated that the source of exposure was a combination of background environmental lead, and ingested spent lead ammunition that has a distinctly lower ${ }^{207} \mathrm{~Pb}$ to ${ }^{206} \mathrm{~Pb}$ ratio (Church et al. 2006).

New models have been developed to estimate tissue concentration and distribution of legacy and emerging contaminants in wildlife. For example, a toxicokinetic model in the developing herring gull embryo predicts lipid mass balance and distribution of PCBs between the embryo, and yolk and albumen compartment (Drouillard et al. 2003). The model predicts that greatest PCB concentrations in the embryo occur during pipping, or shortly thereafter, when yolk lipids have been completely absorbed into the embryo, which is consistent with empirical data. Retention and elimination half-lives have also been modeled for numerous PCB and PBDE congeners in juvenile and adult American kestrels (Falco sparverius) (Drouillard et al. 2001, 2007). A bioenergetic-based model for tree swallow (Tachycineta bicolor) nestlings has been used to quantitatively examine factors (weight-normalized food consumption) and processes (growth dilution) that influence PCB bioaccumulation (Nichols et al. 1995, 2004). Several kinetic models have been developed for mercury in birds, and one such model with a bioenergetics-based component has been used to predict blood mercury concentration as a function of food intake, food mercury content, body mass, and mercury absorption and elimination in common loon (Gavia immer) chicks (Karasov et al. 2007). Work has been initiated on physiological-based pharmacokinetic models for some chlorinated hydrocarbons, methylmercury, and anticoagulant rodenticides in wild birds. Such models permit calculation of tissue concentrations (internal dose) of contaminants for a variety of administered doses, and support interspecific extrapolations for risk assessments. Application of uncertainty factors in estimating toxicity reference values have become well-accepted, and are now used to estimate adverse effect concentrations for toxicant intake (e.g., milligrams per kilogram body weight per day), concentrations in media, and tissue-based toxicant concentrations (micrograms per day) (USACHPPM 2000). Using this approach, predicted no effect concentrations for perfluorooctane sulfonate (PFOS) in the diet (i.e., $0.013 \mathrm{mg}$ PFOS $/ \mathrm{kg}$ body weight/day) and in the liver, serum, and egg yolk $(0.08 \mu \mathrm{g}$ PFOS/g wet weight, $0.15 \mu \mathrm{g}$ PFOS $/ \mathrm{mL}$, and $1 \mu \mathrm{g}$ PFOS $/ \mathrm{mL}$, respectively) of a generic female top-level avian predatory species have been generated (Newsted et al. 2005). Statistical techniques are now being used to derive tissue concentrations associated with toxicological benchmarks. Buekers et al. (2009) have recently calculated the fifth percentile hazard concentration (HC5) of blood lead levels associated with a no observed effect concentration (NOEC) in bird and mammals. Theoretically, at blood lead concentrations below the $\mathrm{HC} 5,95 \%$ of all higher vertebrates will be protected. As these examples illustrate, tissue concentrations are being used to answer increasingly more complex questions. Although tissue concentrations are still used to examine the fate of a particular organism, they are also used to elucidate contaminant hazards to populations and to ecosystems.

\subsection{CASE HISTORY: MERCURY IN WILD BIRDS}

Mercury ( $\mathrm{Hg}$ ) exposure has long been considered a potentially serious threat to the health of both humans and wildlife. The ecotoxicological literature on $\mathrm{Hg}$ is substantial, having evolved over many 
years, and serves to illustrate some of the problems faced by ecotoxicologists when trying to evaluate injury based on tissue contaminant concentrations. The fate of $\mathrm{Hg}$ in the environment is complex. For example, $\mathrm{Hg}$ originates from both natural sources and industrial processes; it may be released into the environment in a number of different chemical forms; it may be chemically interconverted within the abiotic environment; and it may be metabolized by microorganisms to form either methyl $\mathrm{Hg}$ or inorganic $\mathrm{Hg}$, which differ considerably in dietary absorption, tissue distribution, and toxicity in exposed wildlife. Furthermore, the chemical forms of $\mathrm{Hg}$ may be changed within some organs (e.g., demethylation by liver), further complicating interpretation of wildlife tissue concentrations. The principles learned from the literature on $\mathrm{Hg}$ are applicable to other less well-studied environmental contaminants.

Mercury first received attention as a toxicological issue for wildlife in the 1950s and 1960s when elevated $\mathrm{Hg}$ concentrations and poisonings were reported in a wide variety of seed-eating birds and small mammals, and their predators. In these cases, the ultimate source of $\mathrm{Hg}$ exposure in small granivores was the consumption of agricultural seeds (mainly wheat, barley, and oats) coated with alkyl $\mathrm{Hg}$ fungicide compounds (commonly methylmercury dicyandiamide). Predators, including raptorial birds and various carnivorous mammals, were in turn poisoned after feeding on $\mathrm{Hg}$-poisoned prey. Although poisoning of wildlife from this $\mathrm{Hg}$ source occurred in a number of different countries, the most comprehensive report of the phenomenon is probably that of Borg et al. (1969) who described the Swedish experience and concluded that the extent of $\mathrm{Hg}$ poisoning was great enough to have caused population reductions of some affected species. Although Borg et al. (1969) did not indicate specific threshold tissue concentrations for assessing $\mathrm{Hg}$ poisoning in wildlife, they were among the first to suggest that tissue- $\mathrm{Hg}$ (or alkyl $\mathrm{Hg}$ ) concentrations, together with supporting evidence such as behavioral signs and/or characteristic histopathology, were the primary criteria for diagnosing $\mathrm{Hg}$ poisoning in wildlife.

In the 1960s, Hg poisoning of scavenging and fish-eating birds in Japan was related to the industrial release of methyl $\mathrm{Hg}$, the most notable effects occurring in Minamata Bay (Doi et al. 1984). Other major point-sources of $\mathrm{Hg}$ to the environment during the 1960s and 1970s were effluents from pulp mills and chloralkali plants. Aquatic wildlife, especially fish-eating species, sampled from environments affected by these industrial emissions, commonly demonstrated elevated tissue-Hg concentrations (e.g., Fimreite 1974). Occasionally, overt intoxication and mortality of fish-eating wildlife (e.g., wild mink, Wobeser and Swift 1976; and wild otter, Lutra canadensis, Wren 1985) were attributed to $\mathrm{Hg}$ exposure from such sources. In addition, reproductive impairment in wild fish-eating birds was linked to elevated $\mathrm{Hg}$ exposure in such environments (Fimreite 1974, Barr 1986). These early studies examined mainly gross toxicological endpoints such as overt neurotoxicity, reproductive failure, and outright mortality, but sometimes also included histopathological examination for lesions at the cellular level (Tejning 1967, Borg et al. 1969, 1970, Fimreite 1971, Fimreite and Karstad 1971, Aulerich et al. 1974, Heinz 1974, Pass et al. 1975, Heinz and Locke 1976, Wobeser et al. 1976, Finley and Stendell 1978, Finley et al. 1979, Heinz 1979).

A combination of field studies of methyl Hg-exposed animals, and controlled dosing studies using captive animals, helped elucidate tissue and dietary levels of methyl $\mathrm{Hg}$ that were associated with overt toxicity or reproductive impairment (reviewed by Wren et al. 1986, Eisler 1987, Scheuhammer 1987, and more recent reviews by Heinz 1996, Thompson 1996, Burger and Gochfeld 1997, Wolfe et al. 1998). In these studies, it was common to measure and report only total $\mathrm{Hg}$ concentrations in tissues, with the implicit assumption that because exposure was known to be primarily to methyl $\mathrm{Hg}$, tissue levels of total $\mathrm{Hg}$ and methyl $\mathrm{Hg}$ would be essentially identical. This assumption was probably valid for most field and lab studies conducted in the 1960s and 1970s because dietary methyl $\mathrm{Hg}$ exposures in these studies tended to be high, and the duration of exposure was generally fairly brief, certainly not more than a few months. However, the assumption is not valid for scenarios involving chronic, lower-level dietary methyl $\mathrm{Hg}$ exposure. A review of $\mathrm{Hg}$ concentrations in liver and kidney tissue of wildlife that died from $\mathrm{Hg}$ poisoning during the methyl 
Hg-treated grains era, indicated that total $\mathrm{Hg}$ concentrations $>20 \mu \mathrm{g} / \mathrm{g}$ wet weight represent potentially lethal exposures. But in other unrelated studies, much higher concentrations of total $\mathrm{Hg}$ (in some cases, several hundred $\mu \mathrm{g} / \mathrm{g}$ ) in liver of apparently healthy wild animals were reported (e.g., ringed seal, Pusa hispida and bearded seal, Erignathus barbatus, Smith and Armstrong 1975; striped dolphins, Stenella coeruleoalba, Itano et al. 1984; polar bears, Ursus maritimus, Norstrom et al. 1986). An apparently healthy wandering albatross (Diomedea exulans) had liver concentrations $>1000 \mu \mathrm{g} \mathrm{Hg} / \mathrm{g}$ dry weight (Thompson and Furness 1989). How could such dramatically elevated $\mathrm{Hg}$ concentrations fail to be accompanied by signs of severe toxicity? When studied further, $\mathrm{Hg}$ in livers of these and other species was shown to contain variable proportions of organic (methyl) and inorganic forms, with a generally decreasing organic fraction as total $\mathrm{Hg}$ concentrations increased. After absorption from the diet, some methyl $\mathrm{Hg}$ is apparently demethylated in certain tissues in response to increasing methyl $\mathrm{Hg}$ accumulation. Thompson and Furness (1989) demonstrated this phenomenon in a number of seabird species, suggesting that long-lived species with relatively slow molt cycles might be slow to eliminate methyl $\mathrm{Hg}$ through new feather growth and that, therefore, demethylation of methyl $\mathrm{Hg}$ might be an important additional mechanism to reduce the body burden of toxic methyl $\mathrm{Hg}$. More recent studies have addressed apparent species differences in demethylation efficiency among different wild avian species (e.g., Scheuhammer et al. 2008, Eagles-Smith et al. 2009). Taken together, these studies demonstrated that $\mathrm{Hg}$ in liver cannot be assumed to be present primarily as methyl $\mathrm{Hg}$, even though wildlife are exposed primarily to dietary methyl $\mathrm{Hg}$ in fish and other prey. Inorganic $\mathrm{Hg}$ resulting from demethylation in liver is often found in close association with selenium (Se), especially at higher $\mathrm{Hg}$ concentrations (e.g., Koeman et al. 1975, Thompson and Furness 1989, Dietz et al. 1990, Scheuhammer et al. 1998a). Further discussion of the biological $\mathrm{Hg}-\mathrm{Se}$ relationship may be found in accompanying chapters by O'Hara et al. (Chapter 10 of this volume) and Shore et al. (Chapter 18 of this volume).

A major lesson for wildlife toxicologists from the published literature on apparent demethylation of methyl $\mathrm{Hg}$ and accumulation of relatively nontoxic $\mathrm{Hg}-\mathrm{Se}$ complexes is that toxicological assessments should not rely solely on total $\mathrm{Hg}$ concentration measurements in typically analyzed tissues such as liver. This is especially true for long-lived piscivores and other aquatic predators for which years of chronic low-level dietary methyl $\mathrm{Hg}$ exposure may be occurring. In such cases, a high proportion of liver $\mathrm{Hg}$ may be present as inorganic $\mathrm{Hg}$ bound with Se. Scheuhammer et al. (1998a) suggested that total $\mathrm{Hg}$, organic (methyl) $\mathrm{Hg}$, and Se should be analyzed rather than total $\mathrm{Hg}$ alone, when using liver, kidney, and/or brain tissue for toxicological assessments. Wiener et al. (2003) recommended that, when only total $\mathrm{Hg}$ measurements were available, $\mathrm{Hg}$ in skeletal muscle should be analyzed in addition to liver, as almost all of the $\mathrm{Hg}$ in muscle remains methylated. Total $\mathrm{Hg}$ concentrations in liver are not by themselves sufficiently informative to make confident toxicological judgments.

By the 1980s, the use of mercurial seed dressings had been abandoned, and releases of $\mathrm{Hg}$ from the chloralkali and pulp industries had been eliminated or drastically curtailed. At least in North America, some other sources of previously significant environmental Hg releases (e.g., its use in gold mining) had already been phased out by the early 1900s (Eisler 2000). However, some of these older sources of environmental $\mathrm{Hg}$ contamination can still cause substantial exposure in wildlife today. For example, waterbirds nesting in the Carson River basin, contaminated with Hg from gold refining operations during the late 1800 s, continue to be exposed to substantially elevated dietary methyl $\mathrm{Hg}$ concentrations that are of toxicological concern, especially with respect to egg hatchability and health of young (Henny et al. 2002, Hill et al. 2008). Similarly, predatory fish and fisheating wildlife such as bald eagles (Haliaeetus leucocephalus) continue to experience elevated $\mathrm{Hg}$ exposure near a former $\mathrm{Hg}$ mine in central British Columbia, Canada (Weech et al. 2004, 2006). However, in addition to locations experiencing continued $\mathrm{Hg}$ contamination from past point-source emissions, a growing recognition evolved during the 1980s that environments remote from such releases could also contain fish (and consequently fish-eating wildlife) with elevated $\mathrm{Hg}$ concentrations. Predominant among such remote "Hg-sensitive" environments were acid-impacted lakes 
(Björklund et al. 1984, Scheuhammer 1991, Spry and Wiener 1991, Scheuhammer and Blancher 1994), and reservoirs and lakes created by flooding of vegetated land where environmental $\mathrm{Hg}$ methylation and food chain transfer of $\mathrm{Hg}$ are enhanced (Bodaly et al. 1984, Johnson et al. 1991, Hall et al. 2005). Furthermore, in some very remote environments, temporal investigations indicated that $\mathrm{Hg}$ levels in wildlife were increasing near the end of the twentieth century (Monteiro and Furness 1997, Braune et al. 2005), whereas levels were declining in some more industrialized areas (Koster et al. 1996).

In response to the recognition of elevated $\mathrm{Hg}$ concentrations in food chains of certain remote ecosystems, studies of the effects of environmental $\mathrm{Hg}$ exposure in wildlife continued through the 1990s and beyond. A number of field studies sought to characterize exposure and effects in fisheating wildlife in $\mathrm{Hg}$-sensitive habitats, and to better understand the relation between elevated $\mathrm{Hg}$ in wildlife and their prey (Wren et al. 1987a, 1987b, Meyer et al. 1995, DesGranges et al. 1998, Evers et al. 1998, 2003, Scheuhammer et al. 1998b, 2001, Burgess et al. 2005, Champoux et al. 2006). In more recent toxicological studies, emphasis has been placed on clarifying the effects of environmentally realistic dietary methyl $\mathrm{Hg}$ exposures at the molecular (Spalding et al. 2000, Heath and Frederick 2005, Basu et al. 2005, 2006, 2007, 2009, Kenow et al. 2008, Scheuhammer et al. 2008), organismal (reproductive endpoints) (Wren et al. 1987a, 1987b, Heinz and Hoffman 1998, 2003, Dansereau et al. 1999, Albers et al. 2007), and population (Meyer et al. 1998, Moore et al. 1999, Sample and Suter 1999, Evers et al. 2005, 2008, Burgess and Meyer 2008) levels of organization in wild birds and mammals. In addition, species differences in methyl $\mathrm{Hg}$ toxicity in ovo have begun to be explicitly addressed through avian egg injection studies (Heinz et al. 2006, 2009). Contemporary reviews of the ecological impacts and toxicology of methyl $\mathrm{Hg}$ in wildlife have explicitly recognized that current levels of $\mathrm{Hg}$ exposure for some wildlife species in some environments are sufficiently high to be of toxicological concern (Wiener et al. 2003, Scheuhammer et al. 2007, Wolfe et al. 2007). In addition, tissue- $\mathrm{Hg}$ concentrations recognized to be harmful have gradually decreased as increasingly sensitive cellular and biochemical effects have been identified. For example, significant correlations between brain $\mathrm{Hg}$ concentrations and the density of some neurotransmitter receptors in mink have been observed well below the previously estimated lowest observable effect concentration (LOEC) for Hg in mink or otter brain (Scheuhammer et al. 2007). Shore et al. (2010), using species sensitivity distributions, have established egg- $\mathrm{Hg}$ concentrations that are protective of $95 \%$ (HC5) of avian species.

Although fish-eating wildlife generally exhibit substantially higher exposure to dietary methyl $\mathrm{Hg}$ than terrestrial animals, recent research has identified certain terrestrial food chains in forest habitats that appear to concentrate methyl $\mathrm{Hg}$. Some forest songbird species feeding in such food chains can experience dietary methyl $\mathrm{Hg}$ exposure at least as high as fish-eating birds. For example, blood $\mathrm{Hg}$ concentrations exceeding $4 \mu \mathrm{g} / \mathrm{mL}$ were reported in red-eyed vireos (Vireo olivaceus) and Carolina wrens (Thryothorus ludovicianus) (Cristol et al. 2008); these levels exceed the estimated threshold for reproductive impairment in common loons $(2.87 \mu \mathrm{g} / \mathrm{mL}$ in breeding females; Scheuhammer et al. 2007). Spiders (order Araneae), which had methyl Hg concentrations similar to fish preyed upon by belted kingfishers (Megaceryle alcyon), were found to be a major dietary source of methyl $\mathrm{Hg}$ for these terrestrial birds (Cristol et al. 2008). Additional studies are required to better understand the environmental conditions that lead to elevated methyl $\mathrm{Hg}$ concentrations in these terrestrial food webs, and to determine if reproductive or other impairments accompany elevated $\mathrm{Hg}$ exposure in the most at-risk wildlife species.

In summary, $\mathrm{Hg}$ in wildlife has been studied for more than 50 years, and much has been learned regarding its food chain transfer, accumulation, and toxic effects. Recent studies have begun to document subtle, yet important effects of $\mathrm{Hg}$ on behavior, neurochemistry, and endocrine function in wildlife at currently relevant levels of environmental exposure. Insofar as substantial global anthropogenic $\mathrm{Hg}$ emissions will likely continue into the foreseeable future, there will undoubtedly be a need for continued research on ecotoxicology of $\mathrm{Hg}$, and a revisiting of tissue concentration effect thresholds, well into the twenty-first century. 


\subsection{CASE HISTORY: DIOXINS AND PCBs IN WILD BIRDS}

PCBs, polychlorinated dibenzo-p-dioxins (PCDDs), and polychlorinated dibenzofurans (PCDFs) are structurally similar, persistent, and lipophilic chemicals, which have widely contaminated environmental media, where they have the potential to cause toxicological effects in wild birds. PCBs are anthropogenic in origin and were manufactured and widely used until the latter decades of the twentieth century. PCDDs and PCDFs were produced as by-products of industrial processes and combustion, especially of plastic wastes. The chemistry, environmental fate, and toxicology of these chemicals are complex, and hence controversial.

The word "dioxin" became known to the scientific community, and eventually part of the public lexicon, as a result of the death of millions of broiler chickens during the 1950s in parts of the eastern and southwestern United States. The condition was labeled "chick edema disease" as it was characterized by excessive fluid in the pericardial sac and abdominal cavity, subcutaneous edema, liver necrosis, and death beginning at about 3 weeks of age (Friedman et al. 1959). Investigators quickly traced the source to toxic factors present in fatty acid feed supplements obtained from "fleshing greases" produced as a by-product of the hide tanning industry (Wootton and Alexander 1959). Several years of toxicological and chemical research eventually implicated the use of chlorophenolic biocides as hide preservatives, and the identification of PCDDs, particularly 1,2,3,7,8,9hexachlorodibenzo- $p$-dioxin as the main chick edema factor (Higginbotham et al. 1968, Firestone 1973). Verrett, Flick and coworkers dosed both chicks and chick embryos with individual PCDDs and PCDFs providing the first data of potential value for interpreting tissue concentrations (Verrett 1970, Flick et al. 1973).

Concerned over PCDD contaminants in chlorophenolic pesticides, some researchers began to investigate food chain contamination in areas of intensive use. During the 1960s, an estimated 400 $\mathrm{kg}$ of 2,3,7,8-tetrachlorodibenzo-p-dioxin (TCDD) was sprayed by the United States military onto the forests of Indochina as a contaminant in the 20 million $\mathrm{kg}$ of the herbicide 2,4,5-T, a component of Agent Orange, used as a chemical warfare agent (Huff and Wassom 1974). A 1970 survey of Vietnamese rivers found that whole body samples of catfish (Siluridae), for example, from the Dong Nai River had mean 2,3,7,8-TCDD concentrations of $810 \mathrm{pg} / \mathrm{g}$ wet weight (Baughman and Meselson 1973). There appears to have been no published attempt to extrapolate that finding to wildlife; however, assuming that the reported concentrations in fish were accurate within an order of magnitude, and using the biomagnification factor from fish to fish-eating birds for 2,3,7,8-TCDD of 32 (Braune and Norstrom 1989), aquatic birds feeding in that system would have accumulated sufficient TCDD alone to cause overt toxicity, even in less sensitive species.

While a number of laboratories were investigating environmental contamination by dioxins, in 1966 during gas chromatographic analysis for DDT, Jensen identified a series of PCB compounds (Jensen 1966, Jensen et al. 1969). Risebrough and coworkers (1968) soon reported that birds from the remotest areas of the globe were contaminated by PCBs. Studies of PCB toxicity to birds, particularly chickens, soon followed (Chapter 14 of this volume, reviewed by Eisler 1986, Bosveld and Van den Berg 1994, Barron et al. 1995). Compared to many of the organochlorine insecticides in wide use at that time, acute toxicity of PCBs was low and also varied according to the degree of chlorination of the Aroclor mixture (Hill et al. 1975). In cases of experimentally caused mortality, the brain was the most reliable diagnostic tissue for determining lethal concentrations of PCBs (e.g., brain: 300-400 $\mu \mathrm{g} / \mathrm{g}$ wet weight in pheasants, Dahlgren et al. 1972; 76-445 $\mu \mathrm{g} / \mathrm{g}$ in fish-eating birds, Koeman et al. 1973; and $310 \mu \mathrm{g} / \mathrm{g}$ in passerines, Stickel et al. 1984; liver: 70-697 $\mu \mathrm{g} / \mathrm{g}$ in Bengalese finch, Lonchura striata, Prestt et al. 1970). A study of lethal effects on the great cormorant (Phalacrocorax carbo) reported a lower brain threshold, and attempted to determine if that species was more sensitive or whether results were confounded by furan contamination from the Clophen A60 dosing mixture (Koeman et al. 1973). Mortality and residue analyses of ring-billed gulls (Larus dalawarensis) in the early 1970s on the Great Lakes also implicated PCBs as a possible causative factor (Sileo et al. 1977). 
During the late 1960s, scientists began to assess the effects of PCB mixtures on avian reproduction, principally focusing on chickens, but also including other galliform and nongalliform species. It soon became evident that, as with dioxins, chickens were more sensitive than other tested species. Some researchers employed the egg injection technique, and findings varied according to factors such as the Aroclor mixture, injection site, and dosing vehicle. For example, $5 \mu \mathrm{g} / \mathrm{g}$ of Aroclor 1242 injected into chicken eggs on day zero of incubation caused a variety of malformations in embryos, and other effects in hatched chicks (Carlson and Duby 1973). Peakall and Peakall (1973) conducted a feeding study with Aroclor 1254 in the ring dove (Streptopelia risoria), and showed that embryonic mortality increased with egg concentrations. In subsequent experiments with artificially incubated eggs, they found that the embryonic mortality was caused by altered parental behavior, specifically reduced nest attentiveness.

By the late 1970s, surveys of PCB contamination revealed, not surprisingly, that wildlife in heavily industrialized ecosystems, such as the North American Great Lakes and the Baltic region, were particularly contaminated, and thus those regions became foci for investigating the effects of environmental contaminants on birds (Gilman et al. 1977, Falandysz 1980) (Table 1.1). As early as 1970, colonies of gulls (Larus spp.) and terns (Sterna spp.) nesting on Lakes Ontario and Michigan, were exhibiting high rates of nest failure associated with embryotoxicity and various deformities among hatched birds (Gilbertson 1974, 1975). Mean PCB concentrations (as Aroclor 1254:1260) in herring gull eggs were $142 \mu \mathrm{g} / \mathrm{g}$ wet weight at a colony in Lake Ontario and $92 \mu \mathrm{g} / \mathrm{g}$ at a Lake Michigan colony (Gilman et al. 1977). There were extensive field and laboratory investigations of the Great Lakes avifauna; however, establishing cause-effect linkages, and thus critical concentrations of specific compounds proved problematic. During the period when signs of toxicity were overt, fish-eating bird eggs contained elevated concentrations of a complex mixture of halogenated aromatic contaminants in addition to PCBs, including DDTs, mirex, hexachlorobenzene, and TCDD (Peakall and Fox 1987).

The early research and monitoring of wildlife contamination by PCBs and dioxins was hindered by limitations in analytical chemistry. PCB quantification was based on one or two peaks resolved by packed column gas chromatography (GC), ineffective at separating most individual congeners. With the introduction and widespread use of fused-silica capillary GC columns, greater resolution of compounds was possible, but identification of many peaks remained problematic. In the early 1980s, Mullin et al. (1984) reported the synthesis and relative retention times of all 209 PCB congeners, which allowed researchers to comprehensively assess the patterns of PCB congeners present in various environmental media. By comparing patterns of congener peaks among sediment, forage fish, and birds, Norstrom (1988) showed which congeners were more resistant to metabolic degradation and therefore, tended to bioaccumulate, and he suggested some general structural properties governing bioaccumulation in birds.

Given the findings of widespread embryotoxicity, including deformities, during the late 1960s and early 1970s, the presence of 2,3,7,8-TCDD in the Great Lakes food chain had been hypothesized, but could not be established with analytical methods employed at that time (Bowes et al. 1973). By the early 1980s, the availability of high resolution mass spectrometry (MS) combined with GC/MS enabled the quantification of PCDDs and PCDFs in tissue samples at $<10 \mathrm{pg} / \mathrm{g}$. A new GC/MS analytical method was developed and applied to a spatial survey of the Great Lakes, and to a temporal survey made possible by retrospective analysis of herring gull egg samples archived in the Canadian Wildlife Service National Specimen Bank (Elliott et al. 1988). The results showed that eggs from a colony in Lake Ontario contained mean concentrations of 2, 3, 7, 8-TCDD that were greater than $1000 \mathrm{pg} / \mathrm{g}$ in 1971, and which had decreased to about $100 \mathrm{pg} / \mathrm{g}$ by 1980 (Stalling et al. 1985). The GC/MS method enabled examination of PCDD and PCDF patterns in environmental media and biota, demonstrating that chlorine substitution at the 2, 3, 7, and 8 carbon positions conferred resistance to metabolic breakdown, indicating therefore that those compounds tended to bioaccumulate (Stalling et al. 1985). 
TABLE 1.1

Some Representative Studies of PCBs and Dioxins in Wild Birds

\section{Species}

Western grebe,

Aechmophorus

occidentalis

Black-footed albatross,

Phoebastria nigripes

Northern gannet,

Morus bassanus

Great cormorant,

Phalacrocorax carbo

Double-crested

cormorant,

Phalacrocorax auritus

Black-crowned night
heron, Nycticorax
nycticorax
Great blue heron,
Ardea herodias
Wood duck, Aix sponsa

Herring gull, Larus
argentatus
Glaucous gull, Larus
hyperboreus
Common tern, Sterna
hirundo

Forster's tern, Sterna

forsteri

Caspian tern,

Hydroprogne caspia

Atlantic puffin,

Fratercula arctica

White-tailed sea-eagle,

Haliaeetus albicilla

Bald eagle, Haliaeetus

leucocephalus

Osprey, Pandion

haliaetus

American kestrel,

Falco sparverius

\section{Location}

British Columbia

North Pacific

Eastern Canada

Netherlands,

Japan

Great Lakes

Eastern U.S.

Arkansas

Great Lakes

Norway

Great Lakes,

Netherlands

Great Lakes

Great Lakes

Great Britain

Sweden

United States,

British

Columbia

Pacific Northwest,

Wisconsin,

Ontario

Lab study

\section{Contaminants}

PCBs, PCDDs, PCDFs, OCs

PCBs, OCs

PCBs, DDE,

OCs

PCBs

PCBs, OCs

PCBs, OCs, PCDDs,

PCDFs

PCDDs, PCDFs Reproductive

TCDD, TCDF

PCBs, OCs

PCBs, OCs

PCBs, PCDDs, PCDFs

PCBs, TCDD

PCBs, OCs

PCBs

PCBs, PCDDs, PCDFs, OCs

PCBs, OCs, PCDDs, PCDFs

PCBs, PCDDs, PCDFs

CB-126, CB-77, Aroclor mixture failure

Poor reproductive success, egg

injection

Study Type

Monitoring

Monitoring

Poor reproductive

success

Reports of

mortality,

monitoring

Deformities,

variable

reproductive

success

Monitoring study

Poor reproductive success

Monitoring study

Deformities, poor reproductive success

Reproductive problems

Monitoring

Toxicological field experiment

Poor reproductive success

Poor reproductive success

Monitoring, industrial site assessment

Egg injection study, feeding study

\section{Reference}

Elliott and Martin 1998

Auman et al. 1996

Elliott et al. 1988

Koeman et al. 1973,

Guruge and Tanabe 1994

Larson et al. 1996,

Powell et al. 1998,

Custer et al. 1999

Rattner et al. 1997, 2000, 2001

Elliott et al. 1989, 2001a,

Bellward et al. 1990

White and Seginak 1994, Augspurger et al. 2008

Gilman et al. 1977

Bustnes et al. 2001

Gilbertson et al. 1976,

Bosveld et al. 1995

Kubiak et al. 1989,

Harris et al. 1993

Struger and Weseloh 1985

Harris and Osborne 1981

Helander et al. 2002

Wiemeyer et al. 1993,

Elliott and Harris 2001

Elliott et al. 2001a, Henny et al. 2009, Woodford et al. 1998,

DeSolla and Martin 2009

Hoffman et al. 1998,

Fernie et al. 2001, 2003 
TABLE 1.1 (continued)

\section{Some Representative Studies of PCBs and Dioxins in Wild Birds}

\begin{tabular}{|c|c|c|c|c|}
\hline Species & Location & Contaminants & Study Type & Reference \\
\hline $\begin{array}{l}\text { Northern bobwhite, } \\
\text { Colinus virginianus }\end{array}$ & Lab study & CB-126, CB-77 & $\begin{array}{l}\text { Egg injection } \\
\text { study }\end{array}$ & Hoffman et al. 1998 \\
\hline $\begin{array}{c}\text { Ring-necked pheasant, } \\
\text { Phasianus colchicus }\end{array}$ & Lab study & 2,3,7,8-TCDD & $\begin{array}{c}\text { Feeding study, } \\
\text { egg injection }\end{array}$ & Nosek et al. 1992, 1993 \\
\hline $\begin{array}{l}\text { Great horned owl, } \\
\text { Bubo virginianus }\end{array}$ & $\begin{array}{l}\text { Kalamazoo River, } \\
\text { Michigan }\end{array}$ & PCBs & $\begin{array}{l}\text { Contaminated } \\
\text { site assessment }\end{array}$ & Strause et al. 2007a, 2007b \\
\hline $\begin{array}{l}\text { Tree swallow, } \\
\text { Tachycineta bicolor }\end{array}$ & $\begin{array}{l}\text { New York, } \\
\text { Massachusetts, } \\
\text { Rhode Island }\end{array}$ & PCBs, TCDD & $\begin{array}{l}\text { Contaminated } \\
\text { site assessment }\end{array}$ & $\begin{array}{l}\text { McCarty and Secord 1999a, } \\
\text { 1999b, Custer et al. 2003, } \\
2005\end{array}$ \\
\hline $\begin{array}{l}\text { Eastern bluebird, } \\
\text { Sialia sialis }\end{array}$ & $\begin{array}{r}\text { Wisconsin, } \\
\text { Michigan }\end{array}$ & TCDD & $\begin{array}{l}\text { Lab study, } \\
\text { contaminated } \\
\text { site assessment }\end{array}$ & $\begin{array}{l}\text { Thiel et al. 1988, } \\
\text { Neigh et al. } 2007\end{array}$ \\
\hline $\begin{array}{l}\text { American robin, } \\
\text { Turdus migratorius }\end{array}$ & Massachusetts & PCBs & $\begin{array}{l}\text { Contaminated } \\
\text { site assessment }\end{array}$ & Henning et al. 2003 \\
\hline $\begin{array}{l}\text { Eurasian dipper, } \\
\text { Cinclus cinclus }\end{array}$ & Wales & PCBs & $\begin{array}{r}\text { Point source } \\
\text { assessment }\end{array}$ & Ormerod et al. 2000 \\
\hline $\begin{array}{l}\text { American dipper, } \\
\text { Cinclus mexicanus }\end{array}$ & $\begin{array}{l}\text { British Columbia } \\
\text { coastal } \\
\text { watershed }\end{array}$ & PCBs, OCs & $\begin{array}{l}\text { Source } \\
\text { determination }\end{array}$ & Morrissey et al. 2005 \\
\hline $\begin{array}{l}\text { Starling, Sturnus } \\
\text { vulgaris }\end{array}$ & Illinois & PCBs & $\begin{array}{l}\text { Contaminated } \\
\text { site assessment }\end{array}$ & Arenal et al. 2004 \\
\hline
\end{tabular}

Availability of a full range of compounds for toxicity testing advanced understanding of the structure-activity relationships of the 17 various 2,3,7,8-substituted PCDDs and PCDFs and the structurally similar non-ortho and mono-ortho PCB congeners. That similarity in structure and effects furthered the theory that there was a common mechanism of action that hinged on the binding to the cytosolic aryl hydrocarbon (Ah) receptor protein, translocation into the nucleus and induction of gene transcription and corresponding proteins (Poland and Knutson 1982). Ranking of potencies for individual congeners relative to 2,3,7,8-TCCD resulted in development of the toxic equivalence factor (TEF) scheme, whereby the toxicity of complex mixtures could be estimated by multiplying each congener concentration in a given sample by its TEF and summing the results of the multiple congeners to obtain the TCDD TEQ concentration of the sample (Safe 1984, 1990). An expert panel recommended avian-specific TEFs, now in wide usage (Van den Berg et al. 1998); however, recent experiments have reported that 2,3,7,8-TCDF may be more toxic than 2,3,7,8-TCDD in some bird species, while 2,3,4,7,8-pentaCDF may be tenfold or more toxic to Japanese quail (Coturnix japonica), than TCDD, requiring a reassessment of avian TEFs (Cohen-Barnhouse et al. 2008).

Brunström and coworkers (Brunström 1988, 1990, Brunström and Andersson 1988, Brunström and Lund 1988) conducted a series of egg injection experiments using chickens and other avian species. Those and other studies provided avian-specific data on the relative potencies of various PCB congeners, and further demonstrated that the chicken was in a class of its own in relative sensitivity to dioxin-like compounds, while the pheasant and the turkey (Melleagris gallopavo) were intermediate in sensitivity, with other species such as ducks and gulls being much less sensitive. Meanwhile, Nosek et al. $(1992,1993)$ studied the toxicology of TCDD in more depth using the pheasant as a model species.

Congener-specific analytical techniques were employed in field and laboratory investigations of ongoing health problems including poor reproductive success of bird populations in the Great Lakes. Given the similarity between the apparent syndrome in that region and chick edema disease, 
Gilbertson and coworkers $(1983,1991)$ developed the concept of the Great Lakes Embryo Mortality, Edema and Deformities Syndrome (GLEMEDS). By the late 1980s, the non-ortho PCBs were suggested as the likely causative factor, because of their wide distribution, greater environmental concentrations, and dioxin-like toxicity. Kubiak et al. (1989) investigated a Forster's tern (Sterna forsteri) colony in the Green Bay region of Lake Michigan that was exhibiting what was later considered GLEMEDS-type signs of toxicity. Their egg-swap studies in particular pointed toward a parental behavioral mechanism to explain lower productivity, rather than embryotoxicity. A subsequent study of those birds suggested NOAELs for PCBs and for hatching success (Harris et al. 1993). Studies of common terns (Sterna hirundo) in North America (e.g., Hoffman et al. 1993), and in Europe (Becker et al. 1993, Bosveld et al. 2000), reported some sublethal effects on chick growth and development, but no clear evidence of PCB effects on hatching success. Reproduction and contaminants, particularly elevated PCB concentrations were investigated by Struger and Weseloh (1985) in Great Lakes Caspian terns (Sterna caspia), and despite relatively high concentrations of PCBs, there were no apparent effects on productivity.

Of particular concern to many researchers were the continued reports during the early 1990s of deformed nestlings in the Great Lakes, considered by some to be a clear diagnostic of poor fitness in wildlife. Clustered incidences of bill deformities among double-crested cormorants (Phalacrocorax auritus) nesting at Lake Michigan colonies were regularly reported. Ludwig et al. (1996) and Giesy et al. (1994) considered that the correlative evidence was sufficient to implicate PCBs as a chemical driver of deformities in Great Lakes cormorants. It has, however, proven difficult to conclusively establish cause and effect between the observed deformities and PCB concentrations in the field, given inconsistency in laboratory results, and potential confounding factors such as disease and genetics, which are discussed more thoroughly in Chapter 14.

In the mid-1980s, eggs of aquatic birds from the Pacific coast of Canada were found with high concentrations and an unusual pattern of PCDDs and PCDFs (Elliott et al. 1989). Work with great blue herons (Ardea herodias) explored possible links between colony failures and increasing PCDD and PCDF contamination from forest industry sources. Throughout the 1990s, field work was conducted on a variety of potentially vulnerable species, including herons, cormorants, bald eagles, osprey (Pandion haliaetus), tree swallows, and various waterfowl species, which described spatial and temporal patterns in contamination, and successfully established linkages with specific forest industry sources (Elliott and Martin 1994, Elliott et al. 1996a, 2001a, Harris and Elliott 2000, Harris et al. 2003). A complementary series of laboratory studies employing artificial incubation and egg injection explored the toxicological aspects in more depth, and generated data useful for recommending criteria for interpreting tissue concentrations of PCDDs in a number of avian species (Bellward et al. 1990, Sanderson et al. 1994a, 1994b, Sanderson and Bellward 1995, Elliott et al. 1996b, 2001b, Janz and Bellward 1996). The contamination and potential effects of PCDDs and PCDFs from the pulp and paper industry were also studied in fish-eating and insectivorous birds from other locations in North America (Champoux 1996, Wayland et al. 1998, Woodford et al. 1998, Custer et al. 2002).

Given its conservation status until the mid-1990s as federally endangered in the United States and in some Canadian provinces, and its position as a top predator, the role of contaminants in the decline of the bald eagle was widely investigated. Nests in many regions of North America were visited regularly to document reproduction and to salvage unhatched eggs for contaminant analysis. Statistically significant negative associations were found between productivity and various contaminants, including PCBs, while DDE effects on shell quality was identified as the main determinant (Wiemeyer et al. 1993). In the Great Lakes region, Best et al. (2010) reported that associations continued between PCBs and productivity into at least the late 1990s. To improve the quantity of data obtained, the salvaged egg metric was enhanced by measuring contaminant burdens in blood samples from nestling bald eagles (Bowerman et al. 1995, 1998), an approach also applied in Sweden to the white-tailed sea-eagle (Haliaeetus albicilla). Meanwhile, improved analytical techniques also made it possible to measure PCDDs, PCDFs, and non-ortho PCBs in eagle nestlings (Elliott 
and Norstrom 1998). Tentative critical concentrations for PCBs and DDE in nestling eagle blood samples were derived (Elliott and Norstrom 1998) based on regressions between nestling blood and egg samples, which were later modified by Elliott and Harris (2001) and Strause et al. (2007a). As exposure to legacy contaminants such as PCBs was declining in many jurisdictions during the 1990s, some researchers began to directly investigate ecological factors, particularly the relative role of food supply and weather that may interact with contaminant exposure and effects (Elliott et al. 1998, 2005, Dykstra et al. 1998, Gill and Elliott 2003, Hoff et al. 2004, Elliott et al. 2005). Similarly, Helander et al. (2002) studied the ecotoxicology of the congeneric white-tailed sea-eagle for many decades in Sweden, in the process developing critical tissue values for PCBs in eggs.

Field research on the effects of PCBs and other contaminants on productivity and other parameters of birds nesting in the Great Lakes continued through the 1990s and into the present century (e.g., Tillitt et al. 1992, Giesy et al. 1995, Fox et al. 1998, Ryckman et al. 1998, Custer et al. 1999). As with bald eagles, the role of ecological variables was increasingly factored into understanding sources and dynamics of contaminants (Hebert and Weseloh 2006), eventually incorporating tools such as stable isotopes and fatty acid profiles (Hebert et al. 2008). Drouillard and Norstrom (2000) made valuable progress in understanding the pharmokinetics of PCBs in birds, and applied those collective advances to develop a bioenergetics model for contaminant dynamics in wild birds (Norstrom et al. 2007). The ongoing concerns about contamination of birds in the Great Lakes and elsewhere, led to more comparative egg injection studies with TCDD and non-ortho PCBs. These studies furthered the understanding of species variation in sensitivity and provided critical egg concentrations for the double-crested cormorant (Powell et al. 1998), and common tern and American kestrel (Hoffman et al. 1998). Several investigators (Fernie et al. 2001, 2003, Fisher et al. 2001, Smits et al. 2002) carried out a feeding study of an Aroclor mixture with the American kestrel as a laboratory model of predatory and fish-eating birds, which has yielded valuable data on a wide range of reproductive and physiological endpoints.

Currently, widespread restrictions on use of PCBs and the need to regulate dioxin releases have been in place for at least 30 years. There remain, however, numerous point sources of those compounds, associated primarily with waste dumps, and soil and sediment contamination at former manufacturing and storage sites. Birds have been used to determine the exposure and evaluate impacts to wildlife in Canada (Bishop et al. 1999, Harris and Elliott 2000, Ormerod et al. 2000, Kocan et al. 2001, Kuzyk et al. 2003, Jaspers et al. 2006), and particularly in the United States, where investigations of contamination of wild birds have been conducted as part of Natural Resource Damage Assessments. Researchers and risk assessors have looked principally at fish-eating birds and raptors (Williams et al. 1995, Hart et al. 2003, Strause et al. 2007a, 2007b), and increasingly at cavity-nesting passerines (Custer et al. 1998, McCarty and Secord 1999a, 1999b, Arenal et al. 2004). Custer and colleagues $(1998,1999,2002,2003,2005)$ in particular have made effective use of the tree swallow and provided data on various endpoints useful for determining critical tissue concentrations.

Outside of specific hotspot areas, long-term monitoring of PCBs and other contaminants in avian indicator species has continued in some regions, such as the Great Lakes (Norstrom and Hebert 2006), and other North American aquatic environments (Rattner et al. 2004, Toschik et al. 2005, Henny et al. 2009), various marine systems including the Arctic (Barrett et al. 1996, Braune and Simon 2003), the Pacific, and Atlantic coasts of Canada (Elliott et al. 1992, 2001a, Harris et al. 2003), and the Baltic (Bignert et al. 1995). The Arctic has been a focus of ongoing study as biologists from Scandinavia, Canada, and Alaska have investigated the exposure and potential effects of PCBs and other persistent organic pollutants in high trophic-level marine birds, particularly the glaucous gull (Larus hyperboreus), a species, which often preys on other marine birds (Henriksen et al. 1998, Sagerup et al. 2000, 2002, Bustnes et al. 2001, Verreault et al. 2006a, 2007).

Monitoring of PCBs and dioxins in wildlife has been complemented by the use of biomarkers, often measured nondestructively in blood or by bioassay methods, to assess relationships between exposure and various endpoints such as hepatic cytochrome P450-associated monooxygenase 
activities (Fossi et al. 1986, Rattner et al. 1993, 1994, 1997, 2000, Sanderson et al. 1994a, 1994b, Davis et al. 1997, Custer et al. 1998, Feyk et al. 2000, Kennedy et al. 2003, Fox et al. 2007a), gene mutations (Stapleton et al. 2001), porphyrin metabolism (Fox et al. 1988, Kennedy et al. 1998), immune system responses (Grasman and Fox 2001, Grasman et al. 1996, Bustnes et al. 2004, Fox et al. 2007b), thyroid hormone levels (Smits et al. 2002, McNabb and Fox 2003, Saita et al. 2004), retinoids (Spear et al. 1990, Elliott et al. 1996b, 2001b, Kuzyk et al. 2003, Murvoll et al. 2006), sex steroids (Verreault et al. 2006b), stress hormones (Martinovic et al. 2003), disease (Hario et al. 2000), and behavior (McCarty and Secord 1999b). Further developments of analytical methodology have led to surveys of PCB and other organochlorine (OC) metabolites in wild birds and some examination of relations with biomarkers (Fangstrom et al. 2005, McKinney et al. 2006).

Most recently, advances in molecular biology have furthered understanding of the mechanisms of dioxin-like toxicity to birds and of the basis for variation in species sensitivity. The cytochrome P450 response of birds exposed to Ah receptor ligands has been shown to be unique, with birds having two distinct CYP1A isoforms (Gilday et al. 1996, Mahajan and Rifkind 1999). Kennedy et al. (1996) developed avian in vitro assays and showed that the magnitude of in vitro response to CYP1A induction may be predictive of species differences in embryotoxicity in ovo. Application of molecular techniques examined the interspecific variation of response to TCDD-like exposure, and showed that sensitivity is closely associated with differences in the molecular structure of the Ah receptor and to differences in preferential induction of CYP1A isoforms (Head 2006, Karchner et al. 2006, Head and Kennedy 2007, Yasui et al. 2007). Sensitivity to dioxin-like compounds among avian species varies according to amino acid differences in the Ah receptor ligand binding domain (Head et al. 2008). Consistent with previous toxicological data, chickens exhibit high sensitivity, while of particular interest some upland game birds, passerines, and an albatross exhibit moderate sensitivity. All other species tested to date, including raptors, waterbirds, and waterfowl, appear relatively insensitive to dioxin-like toxicity (Head et al. 2008).

In summary, beginning with the identification of the chick edema factor, the collaboration among biologist, chemists, and toxicologists over the past 50 years has successfully investigated many aspects of the exposure and toxicology of PCBs, PCDDs, and PCDFs in birds. Field studies have made correlative links between dioxin-like chemicals and alterations in the metabolic, endocrine, and immune functions of populations of avian top predators and aquatic insectivores. In some instances, reproductive success has been significantly affected, although it has often proved difficult to separate causal factors, including other contaminants and cumulative anthropogenic and natural stressors. The particular sensitivity of the chicken to these chemicals has now been linked to the structure of its Ah receptor. One or two changes in the amino acids of the receptor's binding domain causes greatly reduced sensitivity to dioxins. That likely explains in large part the findings that, despite widespread exposure to PCBs, dioxins, and furans at concentrations that would severely compromise reproduction of chickens, there is limited evidence of a significant impact on populations of wild birds. That contrasts to the population declines associated with DDT and dieldrin, and more recently the veterinarian pharmaceutical, diclofenac. Nevertheless, given the ongoing problems posed by numerous contaminated sites, and the global nature particularly of PCB contamination, we can expect these chemicals to remain an issue for sometime into the current century.

\section{CONCLUSION}

As pointed out in a recent review, the field of wildlife toxicology has been shaped by chemical use and misuse, ecological mishaps, and research in the allied field of human toxicology (Rattner 2009). The development and use of new chemicals, and unexpected and unpredicted contamination problems continue to drive this discipline. In some instances, environmental release of toxicants could have resulted in species extinction (e.g., bald eagle, sparrowhawk, Accipiter nisus, and California condor) had not regulatory and remedial actions been undertaken. Dramatic advances in analytical technology over the past 50 years now permit routine detection and measurement of minute 
quantities of chemicals in a myriad of matrices. However, our greatest challenge remains the extrapolation of exposure data from laboratory and field studies to effects in diverse species and freeranging populations, which are often subject to multiple environmental and toxicological stressors.

\section{REFERENCES}

Adler, F. W. E. 1944. Chemical analysis of organs from lead-poisoned Canada geese. J. Wildl. Manage. 8:83-85.

Albers, P. H. 2003. Petroleum and individual polycyclic aromatic hydrocarbons. In Handbook of ecotoxicology, 2nd edition, eds. D. J. Hoffman, B. A. Rattner, G. A. Burton Jr., and J. Cairns Jr., pp. 341-371. Boca Raton, FL: Lewis Publishing Inc.

Albers, P. H., M. T. Koterba, R. Rossman, W. A. Link, J. B. French, R. S. Bennett, and W. C. Bauer. 2007. Effects of methylmercury on reproduction in American kestrels. Environ. Toxicol. Chem. 26:1856-1866.

Albert, C. A., T. D. Williams, W. R. Cullen, V. Lai, C. A. Morrissey, and J. E. Elliott. 2008. Tissue uptake, mortality and sub-lethal effects of monomethylarsonic acid (MMA (V)) in nestling Zebra Finches (Taeniopygia guttata). J. Toxicol. Environ. Health A 71:353-360.

Arenal, C. A., R. S. Halbrook, and M. J. Woodruff. 2004. European starling (Sturnus vulgaris): avian model and monitor of polychlorinated biphenyl contamination at a superfund site in southern Illinois, USA. Environ. Toxicol. Chem. 23:93-104.

Augspurger, T. P., D. E. Tillitt, S. J. Bursian, S. D. Fitzgerald, D. E. Hinton, and R. T. Di Giulio. 2008. Embryo toxicity of 2,3,7,8-tetrachlorodibenzo-p-dioxin to the wood duck (Aix sponsa). Arch. Environ. Contam. Toxicol. 55:659-669.

Aulerich, R. J., and R. K. Ringer. 1977. Current status of PCB toxicity to mink and effect on their reproduction. Arch. Environ. Contam. Toxicol. 6:279-292.

Aulerich, R. J., R. K. Ringer, and J. Iwamoto. 1974. Effects of dietary mercury on mink. Arch. Environ. Contam. Toxicol. 2:43-51.

Auman, H. J., J. P. Ludwig, C. L. Summer, D. A. Verbrugge, K. L. Froese, T. Colborn, and J. P. Giesy. 1996. PCBS, DDE, DDT, and TCDD-EQ in two species of albratross on Sand Island, Midway Atoll, North Pacific Ocean. Environ. Toxicol. Chem. 16:498-504.

Barker, R. J. 1958. Notes on some ecological effects of DDT sprayed on elms. J. Wildl. Manage. 22:269-274.

Barnett, D. C. 1950. The effect of some insecticide sprays on wildlife. Proceedings of the Thirtieth Annual Conference of Western Association of State Game and Fish Commissioners, pp. 125-134.

Barr, J. F. 1986. Population dynamics of the common loon (Gavia immer) associated with mercury-contaminated waters in north-western Ontario, Can. Wildl. Ser. Occasional Paper 56, Ottawa, Canada, 25 pp.

Barrett, M. W., and L. H. Karstad. 1971. A fluorescent erythrocyte test for lead poisoning in waterfowl. J. Wildl. Manage. 35:109-119.

Barrett, R. T., J. U. Skaare, and G. A. Gabrielsen. 1996. Recent changes in levels of persistent organochlorines and mercury in eggs of seabirds from the Barents Sea. Environ. Pollut. 92:13-18.

Barron, M. G., H. Galbraith, and D. Beltman. 1995. Comparative reproductive and developmental toxicology of PCBs in birds. Comp. Biochem. Physiol. Part C Comp. Biochem. Toxicol. 112:1-14.

Basu, N., K. Klenavic, M. Gamberg, M. O’Brien, R. D. Evans, A. M. Scheuhammer, and H. M. Chan. 2005. Effects of mercury on neurochemical receptor binding characteristics in wild mink. Environ. Toxicol. Chem. 24:1444-1450.

Basu, N., A. M. Scheuhammer, K. Rouvinen-Watt, N. Grochowina, R. D. Evans, M. O'Brien, and H. M. Chan. 2007. Decreased N-methyl-D-aspartic acid (NMDA) receptor levels are associated with mercury exposure in wild and captive mink. Neurotoxicology 28:587-593.

Basu, N., A. M. Scheuhammer, K. Rouvinen-Watt, N. Grochowina, K. Klenavic, R. D. Evans, and H. M. Chan. 2006. Methylmercury impairs components of the cholinergic system in captive mink (Mustela vison). Toxicol. Sci. 91:202-209.

Basu, N., A. M. Scheuhammer, C. Sonne, R. J. Letcher, E. W. Born, and R. Dietz. 2009. Is dietary mercury of neurotoxicological concern to wild polar bears (Ursus maritimus)? Environ. Toxicol. Chem. 28:133-140.

Baughman, R. W., and M. S. Meselson. 1973. An analytical method for detecting TCDD. Environ. Health Perspect. 5:27-35.

Becker, P. H., S. Schuhmanns, and C. Koepff. 1993. Hatching failure in common terns (Sterna hirundo) in relation to environmental chemicals. Environ. Pollut. 79:207-213. 
Bellrose, F. C. 1959. Lead poisoning as a mortality factor in waterfowl populations. Ill. Nat. History Survey Bull. 27:235-288.

Bellward, G. D., et al. 1990. Comparison of dibenzodioxin (PCDD) and dibenzofuran (PCDF) levels with mixed-function oxidase induction in Great Blue Herons. J. Toxicol. Environ. Health 30:33-52.

Bernard, R. F. 1963. Studies of the effects of DDT on birds. Michigan State University Biological Series 2:155-192.

Best, D. A., et al. 2010. Productivity, embryo and eggshell characteristics and contaminants in bald eagles from the Great Lakes, USA, 1986-2000. Environ. Toxicol. Chem. 29:1581-1592.

Bignert, A., K. Litzen, T. Odsjo, M. Olsson, W. Persson, and L. Reutergårdh. 1995. Time-related factors influence the concentrations of sDDT, PCBs and shell parameters in eggs of Baltic guillemot (Uria aalge), 1861-1989. Environ. Pollut. 89:27-36.

Bishop, C. A., N. A. Mahony, S. Trudeau, and K. E. Pettit. 1999. Reproductive success and biochemical effects in tree swallows (Tachycineta bicolor) exposed to chlorinated hydrocarbon contaminants in wetlands of the Great Lakes and St. Lawrence River basin, USA and Canada. Environ. Toxicol. Chem. 18:263-271.

Björklund, I., H. Borg, and K. Johansson. 1984. Mercury in Swedish lakes-its regional distribution and causes. Ambio 13:118-121.

Blus, L. J. 1996. DDT, DDD, and DDE in birds. In Environmental contaminants in wildlife: interpreting tissue concentrations, eds. W. N. Beyer, G. H. Heinz, and A. W. Redmon-Norwood, pp. 49-71. Boca Raton, FL: Lewis Publishing Inc.

Blus, L. J., C. D. Gish, A. A. Belisle, and R. M. Prouty. 1972. Logarithmic relationship of DDE residues to eggshell thinning. Nature 235:376-377.

Bodaly, R. A., R. E. Hecky, and R. J. P. Fudge. 1984. Increases in fish mercury levels in lakes flooded by the Churchill River Diversion, northern Manitoba. Can. J. Fish. Aquat. Sci. 41:682-691.

Borg, K., K. Erne, E. Hanko, and H. Wanntorp. 1970. Experimental secondary methylmercury poisoning in the goshawk (Accipiter g. gentiles L.). Environ. Pollut. 1:91-104.

Borg, K., H. Wanntorp, K. Erne, and E. Hanko. 1969. Alkyl mercury poisoning in terrestrial Swedish wildlife. Viltrevy 6:301-379.

Bosveld, A. T. C., et al. 1995. Effects of PCBs, PCDDs and PCDFs in common tern (Sterna hirundo) breeding in estuarine and coastal colonies in the Netherlands and Belgium. Environ. Toxicol. Chem. 14:99-115.

Bosveld, A. T. C., et al. 2000. Biochemical and developmental effects of dietary exposure to polychlorinated biphenyls 126 and 153 in common tern chicks (Sterna hirundo). Environ. Toxicol. Chem. 19:719-730.

Bosveld, A. T. C., and M. Van den Berg. 1994. Effects of polychlorinated biphenyls, dibenzo-p-dioxins, and dibenzofurans on fish-eating birds. Environ. Rev. 2:147-166.

Bowerman, W. W., J. P. Giesy, D. A. Best, and K. J. Kramer. 1995. A review of factors affecting productivity of bald eagles in the Great Lakes region: implications for recovery. Environ. Health Perspec. 103(Suppl 4):51-59.

Bowerman, W. W., D. A. Best, T. G. Grubb, G. M. Zimmerman, and J. P. Giesy. 1998. Trends of contaminants and effects in bald eagles of the Great Lakes basin. Environ. Monit. Assess. 53:197-212.

Bowes, G. W., B. R. Simoneit, A. L. Burlingame, B. W. de Lappe, and R. W. Risebrough. 1973. The search for chlorinated dibenzofurans and chlorinated dioxins in wildlife populations showing elevated levels of embryonic death. Environ. Health Perspect. 5:191-198.

Braune, B. M., and R. J. Norstrom. 1989. Dynamics of organochlorine compounds in herring gulls: III. Tissue distribution and bioaccumulation in Lake Ontario gulls. Environ. Toxicol. Chem. 8:957-968.

Braune, B. M., and M. Simon. 2003. Dioxins, furans, and non-ortho PCBs in Canadian Arctic seabirds. Environ. Sci. Technol. 37:3071-3077.

Braune, B. M., et al. 2005. Persistent organic pollutants and mercury in marine biota of the Canadian Arctic: an overview of spatial and temporal trends. Sci. Total Environ. 351-352:4-56.

Brunström, B. 1988. Sensitivity of embryos from duck, goose, herring gull, and various chicken breeds to 3,3',4,4'-tetrachlorobiphenyl. Poult. Sci. 67:52-57.

Brunström, B. 1990. Mono-ortho-chlorinated chlorobiphenyls: toxicity and induction of 7-ethoxyresorufin $O$-deethylase (EROD) activity in chick embryos. Arch. Toxicol. 64:1188-1192.

Brunström, B., and L. Andersson. 1988. Toxicity and 7-ethoxyresorufin $O$-deethylase induction potency of coplanar polychlorinated biphenyls (PCBs) in chick embryos. Arch. Toxicol. 62:263-266.

Brunström, B., and J. Lund. 1988. Differences between chick and turkey embryos in sensitivity to 3,3'4,4'tetrachlorobiphenyl and in concentration/affinity of the hepatic receptor for 2,3,7,8-tetra-chlorodibenzop-dioxin. Comp. Biochem. Physiol. C. Comp. Pharmacol. Toxicol. 91:507-512.

Buekers, J., E. S., Redeker, and E. Smolders. 2009. Lead toxicity to wildlife: Derivation of a critical blood concentration for wildlife monitoring based on literature data. Sci. Total Environ. 407:3431-3438. 
Bunyan, P. J., D. M. Jennings, and A. Taylor. 1968a. Organophosphorus poisoning, some properties of avian esterases. J. Agric. Food Chem. 16:326-331.

Bunyan, P. J., D. M. Jennings, and A. Taylor. 1968b. Organophosphorus poisoning, diagnosis of poisoning in pheasants owing to a number of common pesticides. J. Agric. Food Chem. 16:332-339.

Burger, J., and M. Gochfeld. 1997. Risk, mercury levels, and birds: relating adverse laboratory effects to field biomonitoring. Environ. Res. 75:160-172.

Burgess, N. M., and M. W. Meyer. 2008. Methylmercury exposure associated with reduced productivity in common loons. Ecotoxicology 17:83-91.

Burgess, N. M., D. C. Evers, and J.D. Kaplan. 2005. Mercury and other contaminants in Common Loons breeding in Atlantic Canada. Ecotoxicology 14:241-252.

Burnett, J. A. 1999. A passion for wildlife: a history of the Canadian Wildlife Service, 1947-1997. Chapter 8. Wildlife toxicology. Can. Field Nat. 113:121-136.

Bustnes, J. O., V. Bakken, K. E. Erikstad, F. Mehlum, and J. U. Skaare. 2001. Patterns of incubation and nestsite attentiveness in relation to organochlorine (PCB) contamination in glaucous gulls. J. Appl. Ecol. 38:791-801.

Bustnes, J. O., S. A. Hanssen, I. Folstad, K. E. Erikstad, D. Hasselquist, and J. U. Skaare. 2004. Immune function and organochlorine pollutants in arctic breeding glaucous gulls. Arch. Environ. Contam. Toxicol. 47:530-541.

Calvert, J. H. 1876. Pheasant poisoning by swallowing shot. The Field 47 No. 1208, Feb 19, p. 189.

Carlson, R. W., and R. T. Duby. 1973. Embryonic effects of three PCBs in the chicken. Bull. Environ. Contam. Toxicol. 9:261-266.

Carson, R. L. 1962. Silent spring. Boston, MA: Houghton Mifflin. 368 pp.

Champoux, L. 1996. PCBs, dioxins and furans in Hooded Merganser (Lophodytes cucullatus), Common Merganser (Mergus merganser) and mink (Mustela vison) collected along the St.Maurice River near La Tuque, Quebec. Environ. Pollut. 92:147-153.

Champoux, L., D. Masse, D. Evers, O. Lane, M. Plante, and S. T. A. Timmerman. 2006. Assessment of mercury exposure and potential effects on Common Loons (Gavia immer) in Quebec. Hydrobiologia 567:263-274.

Church, M. E., R. Gwiazda, R. W. Risebrough, K. Sorenson, C. P. Chamberlain, S. Farry, W. Heinrich, B. A. Rideout, and D. R. Smith. 2006. Ammunition is the principal source of lead accumulated by California condors re-introduced to the wild. Environ. Sci. Technol. 40:6143-6150.

Clark, D. R. Jr., and R. F. Shore. 2001. Chiroptera. In Ecotoxicology of wild mammals, eds. R. F. Shore and B. A. Rattner, pp. 159-214. Chichester, UK: John Wiley and Sons, Ltd.

Clawson, S. G., and M. F. Baker. 1959. Immediate effects of dieldrin and heptachlor on bobwhites. J. Wildl. Manage. 23:215-219.

Coburn, D. R., J. B. DeWitt, J. V. Derby Jr., and E. Ediger. 1950. Phosphorus poisoning in waterfowl. J. Amer. Pharm. Assoc. 39:151-158.

Coburn, D. R., D. W. Metzler, and R. Treichler. 1951. A study of absorption and retention of lead in waterfowl in relation to clinical evidence of lead poisoning. J. Wildl. Manage. 15:186-192.

Cohen-Barnhouse, A., et al. 2008. Effects of TCDD, TCDF and PeCDF injected into the air cell of Japanese quail (Coturnix japonica) prior to incubation. Abstracts of the 29th Society of Environmental Toxicology and Chemistry North America Annual Meeting. Abstract WP210.

Colborn, T., D. Dumandski, and J. P. Myers. 1996. Our stolen future: are we threatening our fertility, intelligence and survival? A scientific detective story. New York: Dutton Publishing, pp. 306.

Cook, R. S., and D. O. Trainer. 1966. Experimental lead poisoning of Canada geese. J. Wildl. Manage. 30:1-8.

Cristol, D. A., et al. 2008. The movement of aquatic mercury through terrestrial food webs. Science. 320:335.

Custer, C. M., T. W. Custer, P. D. Allen, K. L. Stromborg, and M. J. Melancon. 1998. Reproduction and environmental contamination in tree swallows nesting in the Fox River drainage and Green Bay, Wisconsin, USA. Environ. Toxicol. Chem. 17:1786-1798.

Custer, C. M., T. W. Custer, P. M. Dummer, and K. L. Munney. 2003. Exposure and effects of chemical contaminants on tree swallows nesting along the Housatonic River, Berkshire County, Massachusetts, USA, 1998-2000. Environ. Toxicol. Chem. 22:1605-1621.

Custer, T. W., C. M. Custer, and R. K. Hines. 2002. Dioxins and congener-specific polychlorinated biphenyls in three avian species from the Wisconsin River, Wisconsin. Environ. Pollut. 119:323-332.

Custer, T. W., et al. 1999. Organochlorine contaminants and reproductive success of double-crested cormorants from Green Bay, Wisconsin, USA. Environ. Toxicol. Chem. 18:1209-1217. 
Custer, C. M., T. W. Custer, C. J. Rosiu, and M. J. Melancon. 2005. Exposure and effects of 2,3,7,8-tetrachlorodibenzo-p-dioxin in tree swallows (Tachycineta bicolor) nesting along the Woonasquatucket River, Rhode Island, USA. Environ. Toxicol. Chem. 24:93-109.

Dahlen, J. H., and A. O. Haugen. 1954. Acute toxicity of certain insecticides to the bobwhite quail and mourning dove. J. Wildl. Manage. 18:477-481.

Dahlgren, R. B., R. J. Bury, R. L. Linder, and R. F. Reidinger Jr. 1972. Residue levels and histopathology in pheasants given polychlorinated biphenyls. J. Wildl. Manage. 36:524-533.

Dansereau, M., N. Lariviere, D. D. Tremblay, and D. Belanger. 1999. Reproductive performance of two generations of female semidomesticated mink fed diets containing organic mercury contaminated freshwater fish. Arch. Environ. Contam. Toxicol. 36:221-226.

Davis, J. A., D. M. Fry, and B. W. Wilson. 1997. Hepatic ethoxyresorufin- $O$-deethylase activity and inducibility in wild populations of double-crested cormorants (Phalacrocorax auritus). Environ. Toxicol. Chem. 16:1441-1449.

DesGranges, J.-L., J. Rodrigue, and M. Laperle. 1998. Mercury accumulation and biomagnification in ospreys (Pandion haliaetus) in the James Bay and Hudson Bay regions of Quebec. Arch. Environ. Contam. Toxicol. 35:330-341.

DeSolla, S. R., and P. A. Martin. 2009. PCB accumulation in osprey exposed to local sources in lake sediment. Environ. Pollut. 157:347-355.

DeWitt, J. B. 1955. Effects of chlorinated hydrocarbon insecticides upon quail and pheasants. J. Agric. Food. Chem. 3:672-676.

DeWitt, J. B. 1956. Chronic toxicity to quail and pheasants of some chlorinated insecticides. J. Agric. Food. Chem. 4:863-866.

DeWitt, J. B., J. V. Derby Jr., and G. F. Mangan Jr. 1955. DDT vs. wildlife. Relationships between quantities ingested, toxic effects and tissue storage. J. Amer. Pharm. Assoc. 44:22-24.

DeWitt, J. B., C. M. Menzie, V. A. Adomaitis, and W. L. Reichel. 1960. Pesticidal residues in animal tissues. Trans. N. Amer. Wildl. Conf. 25:277-285.

Dietz, R., C. O. Nielsen, M. M. Hansen, and C. T. Hansen. 1990. Organic mercury in Greenland birds and mammals. Sci. Total Environ. 95:41-51.

Doi, R., H. Ohno, and M. Harada. 1984 Mercury in feathers of wild birds from the mercury-polluted area along the shore of the Shiranui Sea. Sci. Total Environ. 40:155-167.

Drouillard, K. G., and R. J. Norstrom. 2000. Dietary absorption efficiencies and toxicokinetics of polychlorinated biphenyls in ring doves following exposure to Aroclor mixtures. Environ. Toxicol. Chem. 19:2707-2714.

Drouillard, K. G., et al. 2007. Bioaccumulation and biotransformation of 61 polychlorinated biphenyl and four polybrominated diphenyl ether congeners in juvenile American kestrels (Falco sparverius). Environ. Toxicol. Chem. 26:313-324.

Drouillard, K. G., K. J. Fernie, J. E. Smits, G. R. Bortolotti, D. M. Bird, and R. J. Norstrom. 2001. Bioaccumulation and biotransformation of 42 polychlorinated biphenyl in American kestrels (Falco sparverius). Environ. Toxicol. Chem. 20:2514-2522.

Drouillard, K. G., R. J. Norstrom, G. A. Fox, A. Gilman, and D. B. Peakall. 2003. Development and validation of a herring gull embryo toxicokinetic model for PCBs. Ecotoxicology 12:55-68.

Dykstra, C. R., M. W. Meyer, D. K. Warnke, W. H. Karasov, D. E. Andersen, W. W. Bowerman IV, et al. 1998. Low reproductive rates of Lake Superior bald eagles: low food delivery rates or environmental contaminants? J. Great Lakes Res. 24:32-44.

Eagles-Smith, C. A., J. T. Ackerman, J. Yee, and T. L. Adelsbach. 2009. Mercury demethylation in waterbird livers: dose-response thresholds and differences among species. Environ. Toxicol. Chem. 28:568-577.

Ecobichon, D. J. 1996. Toxic effects of pesticides. In Casarett and Doull's Toxicology The Basic Science of Poisons, 5th edition, eds. C. D. Klaassen, M. O. Amdur, and J. Doull, pp. 643-689. New York, NY: McGraw-Hill.

Eisler, R. 1986. Polychlorinated biphenyl hazards to fish, wildlife, and invertebrates: a synoptic review. U.S. Fish Wildl. Ser. Biol. Rep. 85(1.7):72.

Eisler, R. 1987. Mercury hazards to fish, wildlife, and invertebrates: a synoptic review. U.S. Fish Wildl. Ser. Biol. Rep. 85(1.10):90.

Eisler, R. 2000. Biogeochemical, health, and ecotoxicological perspectives on gold and gold mining. Boca Raton, FL: CRC Press, 355 pp.

Elliott, J. E., and M. L. Harris. 2001. An ecotoxicological assessment of chlorinated hydrocarbon effects on bald eagle populations. Rev. Toxicol. 4:1-60. 
Elliott, J. E., and P. A. Martin. 1994. Chlorinated hydrocarbons and shell thinning in eggs of Accipiter hawks in Ontario, 1986-1989. Environ. Pollut. 86:189-200.

Elliott, J. E., and P. A. Martin. 1998. Chlorinated hydrocarbon contaminants in grebes and seaducks wintering on the coast of British Columbia, Canada: 1988-1993. Environ. Mon. Assess. 53:337-362.

Elliott, J. E., and R. J. Norstrom. 1998. Chlorinated hydrocarbon contaminants and productivity of bald eagle populations on the Pacific coast of Canada. Environ. Toxicol. Chem. 17:1142-1153.

Elliott, J. E., R. W. Butler, R. J. Norstrom, and P. E. Whitehead. 1989. Environmental contaminants and reproductive success of great blue herons Ardea herodias in British Columbia, 1986-87. Environ. Pollut. 59:91-114.

Elliott, J. E., M. L. Harris, L. K. Wilson, P. E. Whitehead, and R. J. Norstrom. 2001a. Monitoring temporal and spatial trends in polychlorinated dibenzo- $p$-dioxins (PCDDs) and dibenzofurans (PCDFs) in eggs of great blue heron (Ardea herodias) on the coast of British Columbia, Canada, 1983-1998. Ambio 30:416-428.

Elliott, J. E., I. E. Moul, and K. M. Cheng. 1998. Variable reproductive success of bald eagles on the British Columbia coast. J. Wildl. Manage. 62:518-529.

Elliott, J. E., R. J. Norstrom, S. K. Kennedy, and G. A. Fox. 1988. Trends and effects of environmental contaminants determined from analysis of archived wildlife samples. In Progress in environmental specimen banking, eds. S. A. Wise, and G. M. Zeisler. U.S. National Bureau of Standards Special Publication No. 740:131-142.

Elliott, J. E., et al. 1992. Patterns and trends of organic contaminants in Canadian seabirds, 1968-1990. In Persistent Pollutants in the Marine Environment, eds. C. H. Walker, and D. R. Livingston, pp. 181-194, Oxford: Pergamon Press.

Elliott, J. E., R. J. Norstrom, and G. E. J. Smith. 1996a. Patterns, trends and toxicological significance of chlorinated hydrocarbons and mercury in bald eagle eggs. Archiv. Environ. Contam. Toxicol. 31:354-367.

Elliott, J. E., et al. 1996b. Biological effects of polychlorinated dibenzo-p-dioxins, dibenzofurans, and biphenyls in bald eagle (Haliaeetus leucocephalus) chicks. Environ. Toxicol. Chem. 15:782-793.

Elliott, J. E., et al. 2001b. Assessment of biological effects of chlorinated hydrocarbons in osprey chicks. Environ. Toxicol. Chem. 20:866-879.

Elliott, K. H., C. E. Gill, and J. E. Elliott. 2005. Influence of tides and weather on bald eagle provisioning rates. J. Raptor Res. 39:99-108.

Evers, D. C., et al. 2005. Patterns and interpretation of mercury exposure in freshwater avian communities in northeastern North America. Ecotoxicology 14:193-221.

Evers, D. C., et al. 1998. Geographic trend in mercury measured in Common Loon feathers and blood. Environ. Toxicol. Chem. 17:173-183.

Evers, D. C., et al. 2008. Adverse effects from environmental mercury loads on breeding common loons. Ecotoxicology 17:69-81.

Evers, D. C., K. M. Taylor, A. Major, R. J. Taylor, R. H. Poppenga, and A. M. Scheuhammer. 2003. Common loon eggs as indicators of methylmercury availability in North America. Ecotoxicology 12:69-81.

Fairbrother, A. 2009. Federal environmental legislation in the U.S. for protection of wildlife and regulation of environmental chemicals. Ecotoxicology 18:784-790.

Fairbrother, A., B. T. Marden, J. K. Bennett, and M. J. Hooper. 1991. Methods used in determination of cholinesterase activity. In Cholinesterase-inhibiting insecticides: their impact on wildlife and the environment. Vol. 2 Chemicals in agriculture, ed. P. Mineau, pp. 35-71. New York: Elsevier.

Falandysz, J. 1980. Chlorinated hydrocarbons in gulls from the Baltic south coast. Mar. Pollut. Bull. 11:75-80.

Fangstrom, B., M. Athanasiadou, I. Athanassiadis, P. Weihe, and A. Bergman. 2005. Hydroxylated PCB metabolites in nonhatched Fulmar eggs from the Faroe Islands. Ambio 2005. 34:184-187.

Fernie, K., J. Smits, and G. Bortolotti. 2003. Developmental toxicity of in ovo exposure to polychlorinated biphenyls: I. Immediate and subsequent effects on first-generation nestling American kestrels (Falco sparverius). Environ. Toxicol. Chem. 22:554-560.

Fernie, K. J., J. E. Smits, G. R. Bortolotti, and D. M. Bird. 2001. Reproduction success of American kestrels exposed to dietary polychlorinated biphenyls. Environ. Toxicol. Chem. 20:776-781.

Feyk, L. A., J. P. Giesy, A. T. C. Bosveld, and M. van den Berg. 2000. Changes in cytochrome P4501A activity during development in common tern chicks fed polychlorinated biphenyls, as measured by the caffeine breath test. Environ. Toxicol. Chem. 19:712-718.

Fimreite, N. 1971. Effects of dietary methylmercury on ring-necked pheasants. Can. Wildl. Ser. Occasional Paper 9, Ottawa, Canada, 39 pp.

Fimreite, N. 1974. Mercury contamination of aquatic birds in northwestern Ontario. J. Wildl. Manage. $38: 120-131$. 
Fimreite, N., and L. Karstad. 1971. Effects of dietary methyl mercury on red-tailed hawks. J. Wildl. Manage. 35:293-300.

Finley, M. T., and R. C. Stendell. 1978. Survival and reproductive success of black ducks fed methylmercury. Environ. Pollut. 16:51-64.

Finley, M. T., W. H. Stickel, and R. E. Christensen. 1979. Mercury residues in tissues of dead and surviving birds fed methylmercury. Bull. Environ. Contam. Toxicol. 21:105-110.

Firestone, D. 1973. Etiology of chick-edema disease. Environ. Health Perspect. 5:59-66.

Fisher, A. K. 1893. Report on the ornithology of the Death Valley expedition of 1891, comprising notes on the birds observed in southern California, southern Nevada, and parts of Arizona and Utah. In Part II. The Death Valley Expedition: A biological survey of parts of California, Nevada, Arizona, and Utah, A. K. Fisher, et al., 7-158 North American Fauna No. 7. U.S. Department of Agriculture, Division of Ornithology and Mammalogy, Washington, DC.

Fisher, S. A., et al. 2001. Courtship behavior of captive American kestrels (Falco sparverius) exposed to polychlorinated biphenyls. Arch. Environ. Contam. Toxicol. 41:215-220.

Flick, D. F., D. Firestone, J. Ress, and J. R. Allen. 1973. Studies of the chick edema disease. Poulty Sci. 52:1637-1641.

Forsyth, D. J. 2001. Extrapolation of laboratory tests to field populations. In Ecotoxicology of wild mammals. ecological and environmental toxicology series, eds. R. F. Shore and B. A. Rattner, pp. 577-634. New York: John Wiley and Sons, Ltd.

Fossi, M. C., and C. Leonzio. 1994. Nondestructive biomarkers in vertebrates. Boca Raton, FL: Lewis Publishing, Inc. pp. 345.

Fossi, C., C. Leonzio, and S. Focardi. 1986. Mixed function oxidase activity and cytochrome P-450 forms in black-headed gulls feeding in different areas. Mar. Pollut. Bull. 17:546-548.

Fox, G. A., S. W. Kennedy, R. J. Norstrom, and D. C. Wigfield. 1988. Porphyria in herring gulls: a biochemical response to chemical contamination in Great Lakes food chains. Environ. Toxicol. Chem. 7:831-839.

Fox, G. A., S. Trudeau, H. Won, and K. A. Grasman. 1998. Monitoring the elimination of persistent toxic substances from the Great Lakes: chemical and physiological evidence from adult herring gulls. Environ. Monit. Assess. 53:147-168.

Fox, G. A., D. A. Jeffrey, K. S. Williams, S. W. Kennedy, and K. A. Grasman. 2007a. Health of herring gulls (Larus argentatus) in relation to breeding location in the early 1990s. I Biochemical measures. J. Toxicol. Environ. Health A 70:1443-1470.

Fox, G. A., K. A. Grasman, and G. D. Campbell. 2007b. Health of herring gulls (Larus argentatus) in relation to breeding location in the early 1990s. II Cellular and histopathological measures. J. Toxicol. Environ. Health A 70:1471-1491.

Franson, J. C. 1996. Interpretation of tissue lead residues in birds other than waterfowl. In Environmental contaminants in wildlife: interpreting tissue concentrations, eds. W. N. Beyer, G. H. Heinz, and A. W. Redmon-Norwood, pp. 265-279. Boca Raton, FL: Lewis Publishing Inc.

Friedman, L., D. Firestone, W. Horwitz, D. Banes, M. Anstead, and G. Shue. 1959. Studies of the chick edema disease factor. J. Ass. Offic. Agr. Chem 42:129-140.

Friend, M. 1985. Interpretation of criteria commonly used to determine lead poisoning problem areas. U.S. Fish Wildl. Ser., Fish and Wildlife Leaflet 2, Washington, DC.

Gallagher, B. A. 1918. Experiments in avian toxicology. J. Amer. Vet. Med. Assoc. 54:337-356.

Gallo, M. A. 2001. History and scope of toxicology. In Casarett and Doull's toxicology: The basic science of poisons, 6th edition, ed. C. D. Klaassen, pp. 3-10. New York: McGraw-Hill.

Gay, M. L., A. A. Belisle, and J. F. Patton. 1980. Quantification of petroleum-type hydrocarbons in avian tissue. J. Chromat. 187:153-160.

George, J. L., and W. H. Stickel. 1949. Wildlife effects of DDT dust used for tick control on a Texas prairie. Am. Midland Nat. 42:228-237.

Giesy, J. P., and K. Kannan. 2001. Global distribution of perfluorooctane sulfonate in wildlife. Environ. Sci. Technol. 35:1339-1342.

Giesy, J. P., et al. 1995. Contaminants in fishes from the Great Lakes-influenced sections and above dams of three Michigan Rivers: III. Implications for health of bald eagles. Arch. Environ. Contam. Toxicol. 29:309-321.

Giesy J. P., J. P. Ludwig, and D. E. Tillitt. 1994. Dioxins, dibenzofurans, PCBs and colonial, fish-eating water birds. In Dioxins and health, ed. A. Schecter, pp. 249-307. New York: Plenum Press.

Gilbert, S. G., and A. Hayes. 2006. Milestones in toxicology. http://www.asmalldoseof.org/historyoftox/ Milestones.poster.02.03.06.pdf (accessed September 2, 2008).

Gilbertson, M. 1974. Pollutants in breeding herring gulls in the lower Great Lakes. Can. Field. Nat. $88: 273-280$. 
Gilbertson, M. 1975. A Great Lakes tragedy. Nature Canada 4:22-25.

Gilbertson, M, 1983. Etiology of chick edema disease in herring gulls in the lower Great Lakes. Chemosphere 12:357-370.

Gilbertson, M., T. Kubiak, J. Ludwig, and G. Fox. 1991. Great Lakes embryo mortality edema, and deformities syndrome (GLEMEDS) in colonial fish-eating birds: similarity to chick edema disease. J. Toxicol. Environ. Health 33:455-520.

Gilbertson, M., R. D. Morris, and R. A. Hunter. 1976. Abnormal chicks and PCB residue levels in eggs of colonial birds in the lower Great Lakes (1971-1973). Auk 93:434-434.

Gilday, D., M. Gannon, K. Yutzey, D. Bader, and A. B. Rifkind. 1996. Molecular cloning and expression of two novel avian cytochrome P450 1A enzymes induced by 2,3,7,8-tetrachlorodibenzo-p-dioxin. J. Biol. Chem. 271:33054-33059.

Gill, C. E., and J. E. Elliott. 2003. Influence of food supply and chlorinated hydrocarbon contaminants on breeding success of bald eagles. Ecotoxicology 12:95-111.

Gilman, A. P., G. A. Fox, D. B. Peakall, S. M. Teeple, T. R. Carroll, and G. T. Haymes. 1977. Reproductive parameters and egg contaminant levels of Great Lakes herring gulls. J. Wildl. Manage. 41:458-468.

Grasman, K. A., and G. A. Fox. 2001. Associations between altered immune function and organochlorine contamination in young Caspian terns (Sterna caspia) from Lake Huron, 1997-1999. Ecotoxicology 10:101-114.

Grasman, K. A., G. A. Fox, P. F. Scanlon, and J. P. Ludwig. 1996. Organochlorine-associated immunosuppression in prefledgling Caspian terns and herring gulls from the Great Lakes: an ecoepidemiological study. Environ. Health. Perspect. 104(Suppl4):829-842.

Grinell, G. B. 1894. Lead poisoning. Forest and Stream 42(6):117-118.

Grue, C. E., P. L. Gibert PL, and M. E. Seeley. 1997. Neurophysiological and behavior changes on non-target wildlife exposed to organophosphorus and carbamate pesticides: thermoregulation, food consumption, and reproduction. Amer. Zool. 37:369-388.

Guillette, L. J. Jr., T. S. Gross, G. R. Masson, J. M. Matter, H. F. Percival, and A. R. Woodward. 1994. Developmental abnormalities of the gonad and abnormal sex hormone concentrations in juvenile alligators from contaminated and control lakes in Florida. Environ. Health Perspect. 102:680-688.

Guruge, K. S., and S. Tanabe. 1997. Congener specific accumulation and toxic assessment of polychlorinated biphenyls in common cormorants, Phalacrocorax carbo, from Lake Biwa, Japan. Environ. Pollut. 96:425-433.

Hall, B. D., et al. 2005. Impacts of reservoir creation on the biogeochemical cycling of methyl mercury and total mercury in boreal upland forests. Ecosystems, 8:248-266.

Hall, R. J., and N. C. Coon. 1988. Interpreting residues of petroleum hydrocarbons in wildlife tissues. Biological Report 88(15). Fish Wildl. Ser., U.S. Department of the Interior, Washington, DC. 7 pp.

Hario, M., K. Himberg, T. Hollmén, and E. Rudbäck. 2000. Polychlorinated biphenyls in diseased lesser black-backed gull (Larus fuscus fuscus) chicks from the Gulf of Finland. Environ. Pollut. 107:53-60.

Harris, H. J., T. C. Erdman, G. T. Ankley, and K. B. Lodge. 1993. Measures of reproductive success and PCB residues in eggs and chicks of Forster's tern on Green Bay, Lake Michigan-1988. Arch. Environ. Contam. Toxicol. 25:304-314.

Harris, M. L., and J. E. Elliott. 2000. Reproductive success and chlorinated hydrocarbon contamination in tree swallows (Tachycineta bicolor) nesting along rivers receiving pulp and paper mill effluent discharges. Environ. Pollut. 110:307-320.

Harris, M. P., and D. Osborn. 1981. Effect of a polychlorinated biphenyl on the survival and breeding of puffins. J. Appl. Ecol. 18:471-479.

Harris, M. L., L. K. Wilson, R. J. Norstrom, and J. E. Elliott. 2003. Egg concentrations of polychlorinated dibenzo- $p$-dioxins and dibenzofurans in double-crested (Phalacrocorax auritus) and pelagic ( $P$. pelagicus) cormorants from the Strait of Georgia, Canada, 1973-1998. Environ. Sci. Technol. 37:822-831.

Hart, C. A., I. C. T. Nisbet, S. W. Kennedy, and M. E. Hahn. 2003. Gonadal feminization and halogenated environmental contaminants in common terns (Sterna hirundo): evidence that ovotestes in male embryos do not persist to the prefledgling stage. Ecotoxicology 12:125-140.

Harvey, J. M. 1967. Excretion of DDT by migratory birds. Can. J. Zool. 45:629-633.

Hayes, W. J. Jr. 1991. Introduction. In Handbook of pesticide toxicology, Volume 1 General Principles, eds. W. J. Hayes Jr., and E. R. Laws, Jr., pp. 1-37. New York: Academic Press, Inc.

Head, J. A. 2006. Variation in the cytochrome P4501A response to dioxin-like compounds in avian species. $\mathrm{PhD}$ Thesis, University of Ottawa, Ottawa, ON.

Head, J. A., and S. W. Kennedy. 2007. Differential expression, induction, and stability of CYP1A4 and CYP1A5 mRNA in chicken and herring gull embryo hepatocytes. Comp Biochem Physiol Part C Comp. Biochem. Toxicol. 145:617-624. 
Head, J. A., M. E. Hahn, and S. W. Kennedy. 2008. Key amino acids in the aryl hydrocarbon receptor predict dioxin sensitivity in avian species. Environ. Sci. Technol. 42:7535-7541.

Heath, J. A., and P. C. Frederick. 2005. Relationships among mercury concentrations, hormones, and nesting effort of white ibises (Eudocimus albus) in the Florida Everglades. Auk 122:255-267.

Heath, R. G., J. W. Spann, and J. F. Kreitzer.1969. Marked DDE impairment of mallard reproduction in controlled studies. Nature 224:47-48.

Heath, R. G., J. W. Spann, E. F. Hill, and J. F. Kreitzer. 1972. Comparative dietary toxicities of pesticides to birds. U.S. Fish Wildl. Ser., Special Scientific Report-Wildlife 152:57.

Heaton, S. N., et al. 1995. Dietary exposure of mink to carp from Saginaw Bay, Michigan. 1. Effects on reproduction and survival, and the potential risks to wild mink populations. Arch. Environ. Contam. Toxicol. 28:334-343.

Hebert, C. E., and D. V. C. Weseloh. 2006. Adjusting for temporal change in trophic position results in reduced rates of contaminant decline. Environ. Sci. Technol. 40:5624-5628.

Hebert, C. E., et al. 2008. Restoring picivorous fish populations in the Laurentian Great Lakes causes seabird dietary change. Ecology 89:891-897.

Heinz, G. 1974. Effects of low dietary levels of methyl mercury on mallard reproduction. Bull. Environ. Contam. Toxicol. 11:386-392.

Heinz, G. H. 1979. Methylmercury: reproductive and behavioral effects on three generations of mallard ducks. J. Wildl. Manage. 43:94-401.

Heinz, G. H. 1996. Mercury poisoning in wildlife. In Noninfectious diseases of wildlife, 2nd edition, eds. A. Fairbrother, L. N. Locke, and G. L. Hoff, pp. 118-127. Ames, IA: Iowa State University Press.

Heinz, G. H., and D. J. Hoffman. 1998. Methylmercury chloride and selenomethionine interactions on health and reproduction in mallards. Environ. Toxicol. Chem. 17:139-145.

Heinz, G. H., and D. J. Hoffman. 2003. Embryotoxic thresholds of mercury: estimates from individual mallard eggs. Arch. Environ. Contam. Toxicol. 44:257-264.

Heinz, G. H., and R. W. Johnson. 1981. Diagnostic brain residues of dieldrin: some new insights. In Avian and mammalian wildlife toxicology: second conference, eds. D. W. Lamb and E. E. Kenega, pp. 72-92. Philadelphia: ASTM STP 757.

Heinz, G. H., and L. N. Locke. 1976. Brain lesions in mallard ducklings from parents fed methylmercury. Avian Dis. 20:9-17.

Heinz, G. H., D. J. Hoffman, J. D. Klimstra, K. R. Stebbins, S. L. Kondrad, and C. A. Erwin. 2009. Species differences in the sensitivity of avian embryos to methylmercury. Arch. Environ. Contam. Toxicol. 56:129-138.

Heinz, G. H., D. J. Hoffman, S. L. Kondrad, and C. A. Erwin. 2006. Factors affecting the toxicity of methylmercury injected into eggs. Arch. Environ. Contam. Toxicol. 50:264-279.

Helander, B., A. Olsson, A. Bignert, L. Asplund, and K. Litzén. 2002. The role of DDE, PCB, coplanar PCB and eggshell parameters for reproduction in the white-tailed sea eagle (Haliaeetus albicilla) in Sweden. Ambio 31:386-403.

Henning, M. H., S. K. Robinson, K. J. McKay, J. P. Sullivan, and H. Brucker. 2003. Productivity of American robins exposed to polychlorinated biphenyls, Housatonic River, Massachusetts, USA. Environ. Toxicol. Chem. 22:2783-2788.

Henny, C. J. 2003. Effects of mining lead on birds: a case history at Coeur d'Alene Basin, Idaho. In Handbook of Ecotoxicology, 2nd edition, eds. D. J. Hoffman, B. A. Rattner, G. A. Burton, Jr., and J. Cairns, Jr., pp. 755-766. Boca Raton, FL: Lewis Publishing Inc.

Henny, C. J., L. J. Blus, E. J. Kolbe, and R. E. Fitzner. 1985. Organophosphate insecticide (famphur) topically applied to cattle kills magpies and hawks. J. Wildl. Manage. 49:648-658.

Henny, C. J., E. F. Hill, D. J. Hoffman, M. G. Spalding, and R. A. Grove. 2002. Nineteenth century mercury: Hazard to wading birds and cormorants of the Carson River, Nevada. Ecotoxicology 11:213-231.

Henny, C. J., J. L. Kaiser, and R. A. Grove. 2009. PCDDs, PCDFs, PCBs, OC pesticides and mercury in fish and osprey eggs from Willamette River, Oregon (1993, 2001 and 2006) with calculated biomagnification factors. Ecotoxicology 18:151-173.

Henriksen, E. O., G. W. Gabrielsen, J. U. Skaare, N. Skjegstad, and B. M. Jenssen. 1998. Relationships between PCB levels, hepatic EROD activity and plasma retinol in glaucous gulls. Larus hyperboreus. Mar. Environ. Res. 46:45-49.

Hickey, J. J., and D. W. Anderson. 1968. Chlorinated hydrocarbons and eggshell changes in raptorial and fisheating birds. Science 162:271-273.

Hickey, J. J., J. A. Keith, and F. B. Coon. 1966. An exploration of pesticides in a Lake Michigan ecosystem. J. Appl. Ecol. 3(Suppl.):141-153. 
Higginbotham, G. R., A. Huang, D. Firestone, J. Verrett, J. Ress, and A. D. Campbell. 1968. Chemical and toxicological evaluations of isolated and synthetic chloro derivatives of dibenzo-p-dioxin. Nature 220:702-703.

Hill, E. F. 2003. Wildlife toxicology of organophosphorus and carbamate pesticides. In Handbook of ecotoxicology, 2nd edition, eds. D. J. Hoffman, B. A. Rattner, G. A. Burton Jr., and J. Cairns Jr., 281-312. Boca Raton, FL: Lewis Publishing Inc.

Hill, E. F., and W. J. Fleming. 1982. Anticholinesterase poisoning of birds: field monitoring and diagnosis of acute poisoning. Environ. Toxicol. Chem. 1:27-38.

Hill, E. F., R. C. Heath, J. W. Spann, and J. D. Williams. 1975. Lethal dietary toxicities of environmental pollutants to birds. U.S. Fish Wildl. Ser., Special Scientific Report-Wildlife No. 191, Washington, DC., $61 \mathrm{pp}$.

Hill, E. F., and P. F. P. Henry. 1996. Cyanide. In Noninfectious diseases of wildlife, 2nd edition, eds. A. Fairbrother, L. N. Locke, and G. L. Hoff, pp. 99-107. Ames, IA: Iowa State University Press.

Hill, E. F., C. J. Henny, and R. A. Grove. 2008. Mercury and drought along the lower Carson River, Nevada: II. Snowy egret and black-crowned night-heron reproduction on Lahontan Reservoir, 1997-2006. Ecotoxicology 17:117-131.

Hoff, M. H., M. W. Meyer, J. Van Stappen, and T. W. Fratt. 2004. Relationships between bald eagle productivity and dynamics of fish populations and fisheries in the Wisconsin waters of Lake Superior, 1983-1999. J. Great Lakes Res. 30:434-442.

Hoffman, D. J., C. L. Rice, and T. J. Kubiak. 1996. PCBs and dioxins in birds. In Environmental contaminants in wildlife: interpreting tissue concentrations, eds. W. N. Beyer, G. H. Heinz, and A. W. RedmonNorwood, pp. 165-207. SETAC Special Publication Series. Boca Raton, FL: Lewis Publishing Inc.

Hoffman, D. J., M. J. Melancon, P. N. Klein, J. D. Eisemann, and J. W. Spann. 1998. Comparative developmental toxicity of planar polychlorinated biphenyl congeners in chickens, American kestrels, and common terns. Environ. Toxicol. Chem. 17:747-757.

Hoffman, D. J., G. L. Smith, and B. A. Rattner. 1993. Biomarkers of contaminant exposure in common terns and black-crowned night herons in the Great Lakes. Environ. Toxicol. Chem. 12:1095-1103.

Holmes, W. N. 1984. Petroleum pollutants in the marine environment and their possible effects on seabirds. In Reviews in Environmental Toxicology Vol. 1., ed. E. Hodgson, pp. 252-317. Amsterdam: Elsevier Science Publishers.

Hooper, M. J., P. Mineau, M. E. Zaccagnini, and B. Woodbridge. 2003. Pesticides and international migratory bird conservation. In Handbook of ecotoxicology, 2nd edition, eds. D. J. Hoffman, B. A. Rattner, G. A. Burton Jr., and J. Cairns Jr., pp. 737-754. Boca Raton, FL: Lewis Publishing Inc.

Hotchkiss, N., and R. H. Pough. 1946. Effect on forest birds of DDT used for gypsy moth control in Pennsylvania. J. Wildl. Manage. 10:202-207.

Huff, J. E., and J. S. Wassom. 1974. Health hazards from chemical impurities: chlorinated dibenzodioxins and chlorinated dibenzofurans. Inter. J. Environ. Studies 6:1-17.

Huggett, R. J., R. A. Kimerle, P. M. Mehrle Jr., and H. L. Bergman. 1992 Biomarkers. Biochemical, physiological, and histological markers of anthropogenic stress. SETAC Special Publication Series. Boca Raton, FL: Lewis Publishing, Inc., pp. 347.

Itano, K., S. Kawai, N. Miyazaki, R. Tatsukawa, and T. Fujiyama. 1984. Mercury and selenium levels in striped dolphins caught off the Pacific coast of Japan. Agric. Biol. Chem. 48:1109-1116.

Janz, D. M., and G. D. Bellward. 1996. In ovo 2,3,7,8-tetrachlorodibenzo-p-dioxin exposure in three avian species. I. Effects on thyroid hormones and growth during the perinatal period. Toxicol. Appl. Pharmacol. 139:281-291.

Jaspers, V. L. B., A. Covaci, S. Voorspoels, T. Dauwe, M. Eens, and P. Schepens. 2006. Brominated flame retardants and organochlorine pollutants in aquatic and terrestrial predatory birds of Belgium: levels, patterns, tissue distribution and condition factors. Environ. Pollut. 139:340-352.

Jensen, S. 1966. Report of a new chemical hazard. New Scientist 32:612.

Jensen, S., A. G. Johnels, M. Olsson, and G. Otterlind. 1969. DDT and PCB in marine animals from Swedish waters. Nature 224:247-250.

Jessup, D. A., and F. A. Leighton. 1996. Oil pollution and petroleum toxicity to wildlife. 1996. In Noninfectious Diseases of Wildlife, eds. A. Fairbrother, L. N. Locke, and G. L. Hoff, pp. 141-156. Ames, IA: Iowa State University Press.

Jobling, S., M. Nolan, C. R. Tyler, G. Brighty, and J. P. Sumpter. 1998. Widespread sexual disruption in wild fish. Environ. Sci. Technol. 32:2498-2506.

Johnson, T. A., R. A. Bodaly, and J. A. Mathias. 1991. Predicting fish mercury levels from physical characteristics of boreal reservoirs. Can. J. Fish. Aquat. Sci. 48:1468-1475. 
Karasov, W. H., K. P. Kenow, M. W. Meyer, and F. Fournier. 2007. Bioenergetic and pharmacokinetic model for exposure of common loon (Gavia immer) chicks to methylymercury. Environ. Toxicol. Chem. 26:677-685.

Karchner, S. I., D. G. Franks, S. W. Kennedy, and M. E. Hahn. 2006. The molecular basis for differential dioxin sensitivity in birds: role of the aryl hydrocarbon receptor. Proc. Nat. Acad. Sci. USA 103:6252-6257.

Keith, J. A. 1966. Reproduction in a population of herring gulls (Larus argentatus) contaminated by DDT. J. Appl. Ecol. 3(Suppl.):57-70.

Keith, J. O. 1996. Residue analyses: how they were used to assess hazards of contaminants to wildlife. In Environmental contaminants in wildlife: interpreting tissue concentrations, eds. W. N. Beyer, G. H. Heinz, and A. W. Redmon-Norwood, pp. 1-46. SETAC Special Publication Series. Boca Raton, FL: Lewis Publishing Inc.

Kendall, R. J., and T. E. Lacher Jr. 1994. Wildlife toxicology and population modeling: integrated studies of agroecosystems. Boca Raton, FL: Lewis Publishers Inc., 576 pp.

Kennedy, S. W., G. A. Fox, S. P. Jones, and S. F. Trudeau. 2003. Hepatic EROD activity is not a useful biomarker of polychlorinated biphenyl exposure in the adult herring gull (Larus argentatus). Ecotoxicology 12:153-161.

Kennedy, S. W., G. A. Fox, S. Trudeau, L. J. Bastien, and S. P. Jones. 1998. Highly carboxylated porphyrin concentration: a biochemical marker of PCB exposure in herring gulls. Mar. Environ. Res. 46:65-69.

Kennedy, S. W., A. Lorenzen, S. P. Jones, M. E. Hahn, and J. J. Stegeman. 1996. Cytochrome P4501A induction in avian hepatocyte cultures: a promising approach for predicting the sensitivity of avian species to toxic effects of halogenated aromatic hydrocarbons. Toxicol. Appl. Pharmacol. 141:214-230.

Kenow, K. P., et al. 2008. Effects of methlymercury exposure on glutathione metabolism, oxidative stress, and chromosomal damage in captive-reared common loon (Gavia immer) chicks. Environ. Pollut. 156:732-738.

Kocan, A., J. Petrik, S. Jursa, J. Chovancova, and B. Drobna. 2001. Environmental contamination with polychlorinated biphenyls in the area of their former manufacture in Slovakia. Chemosphere 43:595-600.

Koeman, J. H., H. C. van Velzen-Blad, R. de Vries, and J. G. Vos. 1973. Effects of PCBs and DDE in cormorants and evaluation of PCB residues from an experimental study. J. Reprod. Fertil. Suppl. 19:353-364.

Koeman, J. H., W. S. M. van de Ven, J. J. M. de Goeij, P. S. Tjioe, and J. L. van Haaften. 1975. Mercury and selenium in marine mammals and birds. Sci. Tot. Environ. 3:279-287.

Koster, M. D., D. P. Ryckman, D. V. C. Weseloh, and J. Struger. 1996. Mercury levels in Great Lakes herring gull (Larus argentatus) eggs, 1972-1992. Environ. Pollut. 93:261-270.

Kubiak, T. J., H. J. Harris, L. M. Smith, T. R. Schwartz, J. A. Stalling, L. Sileo, D. E. Docherty, and T. C. Erdman. 1989. Microcontaminants and reproductive impairment of the Forster's tern on Green Bay, Lake Michigan1983. Arch. Environ. Contam. Toxicol. 18:706-727.

Kuzyk, Z. Z. A., N. M. Burgess, J. P. Stow, and G. A. Fox. 2003. Biological effects of marine PCB contamination on black guillemot nestlings at Saglek, Labrador: liver biomarkers. Ecotoxicology 12:183-197.

Lane, R. W., and J. F. Borzelleca. 2007. Harming and helping through time: the history of toxicology. In Principles and Methods of Toxicology, ed. A. W. Hayes, pp. 3-43. New York: Informa Healthcare USA, Inc.

Larson, J. M., et al. 1996. Reproductive success, developmental anomalies, and environmental contaminants in double-crested cormorants (Phalacrocorax auritus). Environ. Toxicol. Chem. 15:553-559.

Levine, B. 2003. Postmortem forensic toxicology. In Principles of forensic toxicology, ed. B. Levine, pp. 3-13. Washington, DC. American Association for Clinical Chemistry.

Linsdale, J. M. 1931. Facts concerning the use of thallium in California to poison rodents-its destructiveness to game birds, song birds and other valuable wild life. Condor 33:92-106.

Livingston, M. L. 1952. Parathion poisoning in geese. J. Amer. Vet. Med. Assoc. 120:27.

Locke, L. N., G. E. Bagley, and H. D. Irby 1966. Acid-fast intranuclear inclusion bodies in the kidneys of mallards fed lead shot. Bull. Wildl. Dis. Assoc. 2:127-131.

Longcore, J. R., L. N. Locke, G. E. Bagley, and R. Andrews. 1974. Significance of lead residues in mallard tissues. U.S. Fish Wildl. Ser., Special Scientific Report-Wildlife No. 182, 24 pp.

Ludke, J. L., E. F. Hill, and M. P. Dieter. 1975. Cholinesterase (ChE) response and related mortality among birds fed ChE inhibitors Arch. Environ. Contam. Toxicol. 3:1-21.

Ludwig, J. P., et al. 1996. Deformities, PCBs and TCDD-equivalents in double-crested cormorants (Phalacrocorax auritus) and Caspian terns (Hydroprogne caspia) of the upper Great Lakes 1986-1991: testing a cause-effect hypothesis. J. Great Lakes Res. 22:172-197.

Magath, T. B. 1931. Lead poisoning in wild ducks. Proc. Staff Mtg. Mayo Clinic 6:749-752. 
Mahajan, S. S., and A. B. Rifkind. 1999. Transcriptional activation of avian CYP1A4 and CYP1A5 by 2,3,7,8tetrachlorodibenzo- $p$-dioxin: differences in gene expression and regulation compared to mammalian CYP1A1 and CYP1A2. Toxicol. Appl. Pharmacol. 155:96-106.

Martinovic, B., D. R. S. Lean, C. A. Bishop, E. Birmingham, A. Secord, and K. Jock. 2003. Health of tree swallow (Tachycineta bicolor) nestlings exposed to chlorinated hydrocarbons in the St. Lawrence River Basin. Part II. Basal and stress plasma corticosterone concentrations. J. Toxicol. Environ. Health A 66:2015-2029.

McCarthy, J. F., and L. R. Shugart. 1990. Biomarkers of environmental contamination. Boca Raton, FL: Lewis Publishers, Inc.

McCarty, J. P., and A. L. Secord. 1999a. Reproductive ecology of tree swallows (Tachycineta bicolor) with high levels of polychlorinated biphenyl contamination. Environ. Toxicol. Chem. 18:1433-1439.

McCarty, J. P., and A. L. Secord. 1999b. Nest-building behavior in PCB-contaminated tree swallows. Auk 116:55-63.

McKinney, M. A., L. S. Cesh, J. E. Elliott, T. D. Williams, D. K. Garcelon, and R. J. Letcher. 2006. Novel brominated and chlorinated contaminants and hydroxylated analogues among North American west coast populations of bald eagles (Haliaeetus leucocephalus). Environ. Sci. Techol. 40:6275-6281.

McNabb, F. M. A., and G. A. Fox. 2003. Avian thyroid development in chemically contaminated environments: is there evidence of alterations in thyroid function and development? Evolut. Devel. 5:76-82.

Meyer, M. W., D. C. Evers, T. Saulton, and W. E. Braselton. 1995. Common loons (Gavia immer) nesting on low $\mathrm{pH}$ lakes in northern Wisconsin have elevated blood mercury content. Water Air Soil Pollut. 80:871-880.

Meyer, M. W., D. C. Evers, J. J. Hartigan, and P. S. Rasmussen. 1998. Patterns of common loon (Gavia immer) mercury exposure, reproduction, and survival in Wisconsin, USA. Environ. Toxicol. Chem. 17:184-190.

Mineau, P. 1991. Cholinesterase-inhibiting insecticides: their impact on wildlife and the environment. Vol 2 Chemicals in agriculture. New York: Elsevier, $348 \mathrm{pp}$.

Mineau, P., et al. 1999. Poisoning of raptors with organophosphorus and carbamate pesticides with emphasis on Canada, U.S. and U.K. J. Raptor Res. 33:1-35.

Mitchell, R. T., H. P. Blagbrough, and R. C. VanEtten. 1953. The effects of DDT upon the survival and growth of nestling songbirds. J. Wildl. Manage. 17:45-54.

Monteiro, L. R., and R. W. Furness. 1997. Accelerated increase in mercury contamination in North Atlantic mesopelagic food chains as indicated by time series of seabird feathers. Environ. Toxicol. Chem. 16:2489-2493.

Moore, N. W., and D. A. Ratcliffe. 1962. Chlorinated hydrocarbon residues in the egg of a peregrine falcon (Falco peregrinus) from Perthshire. Bird Study 9:242-244.

Moore, D. R. J., B. E. Sample, G. W. Suter, B. R. Parkhurst, and R. S. Teed. 1999. A probabilistic risk assessment of the effects of methylmercury and PCBs on mink and kingfishers along East Fork Poplar Creek, Oak Ridge, Tennessee, USA. Environ. Toxicol. Chem. 18:2941-2953.

Morrissey, C. A., L. I. Bendell-Young, and J. E. Elliott. 2005. Identifying sources and biomagnification of persistent organic contaminants in biota from mountain streams of southwestern British Columbia, Canada. Environ. Sci. Technol. 39:8090-8098.

Morrissey, C. A., C. A. Albert, P. L. Dods, W. R. Cullen, V. Lai, and J. E. Elliott. 2007. Arsenic accumulation in bark beetles and forest birds occupying mountain pine beetle infested stands treated with monosodium methanearsonate (MSMA). Environ. Sci. Technol. 41:1494-1500.

Mullin, M. D., C. M. Pochini, S. McCrindle, M. Romkes, S. H. Safe, and L. M. Safe. 1984. High resolution PCB analysis: synthesis and chromatographic properties of all 209 PCB congeners. Environ. Sci. Technol. 18:468-476.

Murvoll, K. M., J. U. Skaare, E. Anderssen, and B. M. Jenssen. 2006. Exposure and effects of persistent organic pollutants in European shag (Phalacrocorax aristotelis) hatchlings from the coast of Norway. Environ. Toxicol. Chem. 25:190-198.

Neigh, A. M., et al. 2007. Reproductive success of passerines exposed to polychlorinated biphenyls through the terrestrial food web of the Kalamazoo River. Ecotoxicol. Environ. Safety 66:107-118.

Newman, J. R. 1979. Effects of industrial air pollution on wildlife. Biol. Conserv. 15:181-190.

Newsted, J. L., P. D. Jones, K. Coady, and J. P. Geisy. 2005. Avian toxicity reference values for perfluorooctane sulfonate. Environ. Sci. Toxicol. 39:9357-9362.

Nichols, J. W., C. P. Larsen, M. E. McDonald, G. J. Niemi, and G. T. Ankley. 1995. Bioenergetics-based model for accumulation of polychlorinated biphenyls by nestling tree swallows. Tachycineta bicolor. Environ. Sci. Technol. 29:604-612.

Nichols, J. W., K. R. Echols, D. E. Tillitt, A. L. Secord, and J. P. McCarty. 2004. Bioenergetics-based modeling of individual PCB congeners in nestling tree swallows from two contaminated sites on the upper Hudson River, New York. Environ. Sci. Technol. 38:6234-6239. 
Norstrom, R. J. 1988. Bioaccumulation of polychlorinated biphenyls in Canadian wildlife. In Hazards, decontamination, and replacement of PCB, A comprehensive guide, ed. J.-P. Crine, pp. 85-100. New York: Plenum Publishers.

Norstrom, R. J., and C. E. Hebert. 2006. Comprehensive re-analysis of archived herring gull eggs reconstructs historical temporal trends in chlorinated hydrocarbon contamination in Lake Ontario and Green Bay, Lake Michigan, 1971-1982. J. Environ. Monit. 8:835-847.

Norstrom, R. J., T. P. Clark, M. Enright, B. Leung, K. G. Drouillard, and C. R. Macdonald. 2007. ABAM, a model for bioaccumulation of POPs in birds: validation for adult herring gulls and their eggs in Lake Ontario. Environ. Sci. Technol. 41:4339-4347.

Norstrom, R. J., R. E. Schweinsberg, and B. T. Collins. 1986. Heavy metals and essential elements in livers of the polar bear (Ursus maritimus). Sci. Tot. Environ. 48:195-212.

Norstrom, R. J., M. Simon, J. Moisey, B. Wakeford, and D. V. Weseloh. 2002. Geographical distribution (2000) and temporal trends (1981-2000) of brominated diphenyl ethers in Great Lakes Herring gull eggs. Environ. Sci. Technol. 36:4783-4789.

Nosek, J. A., S. R. Craven, J. R. Sullivan, S. S. Hurley, and R. E. Peterson. 1992. Toxicity and reproductive effects of 2,3,7,8-tetrachlorodibenzo- $p$-dioxin in ring-necked pheasant hens. J. Toxicol. Environ. Health 35:187-198.

Nosek, J. A., J. R. Sullivan, S. R. Craven, A. Gendron-Fitzpatrick, and R. E. Peterson. 1993. Embryotoxicity of 2,3,7,8-tetrachlorodibenzo-p-dioxin in the ring-necked pheasant. Environ. Toxicol. Chem. $12: 1215-1222$.

Oaks, J. L., et al. 2004. Diclofenac residues as the cause of vulture population decline in Pakistan. Nature 427:630-633.

Ohlendorf, H. M. 2002. The birds of Kesterson Reservoir: a historical perspective. Aquatic Toxicol. 57:1-10.

Ohlendorf, H. M. 2003. Ecotoxicology of selenium. In Handbook of ecotoxicology, 2nd edition, eds. D. J. Hoffman, B. A. Rattner, G. A. Burton Jr., and J. Cairns Jr., pp. 465-500. Boca Raton, FL: Lewis Publishing Inc.

Ohlendorf, H. M., and R. L. Hothem. 1995. Agricultural drainwater effects on wildlife in central California. In Handbook of ecotoxicology, eds. D. J. Hoffman, B. A. Rattner, G. A. Burton Jr., and J. Cairns Jr., pp. 577-595. Boca Raton, FL: Lewis Publishing Inc.

Ormerod, S. J., S. J. Tyler, and I. Juttner. 2000. Effects of point-source PCB contamination on breeding performance and post-fledging survival in the dipper Cinclus cinclus. Environ. Pollut. 110:505-513.

O'Shea, T. J., and S. Tanabe. 2003. Persistent ocean contaminants and marine mammals: a retrospective overview. In Toxicology of marine mammals, eds. J. G. Vos, G. D. Bossart, M. Fournier, and T. J. O’Shea, pp. 99-134. New York, NY: Taylor and Francis.

Pain, D. J. 1996. Lead in waterfowl. In Environmental contaminants in wildlife: interpreting tissue concentrations, eds. W. N. Beyer, G. H. Heinz, and A. W. Redmon-Norwood, pp. 251-264. SETAC Special Publication Series. Boca Raton, FL: Lewis Publishing Inc.

Pass, D. A., P. B. Little, and L. H. Karstad. 1975. The pathology of subacute and chronic methylmercury poisoning of mallard ducks (Anas platyrhynchos). J. Comp. Pathol. 85:7-21.

Pattee, O. H., and D. J. Pain. 2003. Lead in the environment. In Handbook of ecotoxicology, 2nd edition, eds. D. J. Hoffman, B. A. Rattner, G. A. Burton Jr., and J. Cairns Jr., pp. 373-408. Boca Raton, FL: Lewis Publishing Inc.

Peakall, D. B. 1992. Animal biomarkers as population indicators. New York: Chapman and Hall, 291 pp.

Peakall, D. B. 1996. Dieldrin and other cyclodiene pesticides in wildlife. In Environmental contaminants in wildlife: interpreting tissue concentrations, eds. W. N. Beyer, G. H. Heinz, and A. W. Redmon-Norwood, pp. 73-97. Boca Raton, FL: Lewis Publishing Inc.

Peakall, D. B., and G. A. Fox. 1987. Toxicological investigations of pollutant-related effects in Great Lakes gulls. Environ. Health Perspec. 71:187-193.

Peakall, D. B., and M. L. Peakall. 1973. Effects of a polychlorinated biphenyl on the reproduction of artificially and naturally incubated dove eggs. J. Appl. Ecol. 10:863-868.

Peakall, D. B., and L. R. Shugart. 1993. Biomarker-research and applications in the assessment of environmental health. NATO ASI Series, Ser H, Cell Biology, Vol. 68. Berlin: Springer-Verlag, 119 pp.

Peterle, T. J. 1991. Wildlife toxicology. New York: Van Nostrand Reinhold.

Peters, K. E., C. C. Walters, and J. M. Moldwan. 2005. The Biomarker Guide. I. Biomarkers and isotopes in the environment and human history, 2nd edition. Cambridge: Cambridge University Press, $473 \mathrm{pp}$.

Phillips, J. C., and F. C. Lincoln. 1930. American waterfowl, their present situation and the outlook for their future. New York: Houghton Mifflin Co., 312 pp. 
Poland, A., and J. C. Knutson. 1982. 2,3,7,8-Tetrachlorodibenzo-p-dioxin and related halogenated aromatic hydrocarbons: examination of the mechanism of action. Ann. Rev. Pharmacol. Toxicol. 22:517-554.

Post, G. 1952. The effects of aldrin on birds. J. Wildl. Manage. 16:492-497.

Powell, D. C., et al. 1998. Effects of 3,3',4,4',5-pentachlorobiphenyl and 2,3,7,8-tetrachlorodibenzo- $p$-dioxin injected into the yolks of double-crested cormorant (Phalacrocorax auritus) eggs prior to incubation. Environ. Toxicol. Chem. 17:2035-2040.

Prestt, I., D. J. Jefferies, and M. W. Moore. 1970. Polychlorinated biphenyls in wild birds in Britain and their avian toxicity. Environ. Pollut. 1:3-26.

Ratcliffe, D. A. 1967. Decrease in eggshell weight in certain birds of prey. Nature 215:208-210.

Rattner, B. A. 2009. History of wildlife toxicology. Ecotoxicology 18:773-783.

Rattner, B. A., J. S. Hatfield, M. J. Melancon, T. W. Custer, and D. E. Tillitt. 1994. Relation among cytochrome $\mathrm{P} 450, \mathrm{~A} h$-active PCB congeners and dioxin equivalents in pipping black-crowned night-heron embryos. Environ. Toxicol. Chem. 13:1805-1812.

Rattner, B. A., D. J. Hoffman, M. J. Melancon, G. H. Olsen, S. R. Schmidt, and K. C. Parsons. 2000. Organochlorine and metal contaminant exposure and effects in hatching black-crowned night herons (Nycticorax nycticorax) in Delaware Bay. Arch. Environ. Contam. Toxicol. 39:38-45.

Rattner, B. A., et al. 2004. Contaminant exposure and reproductive success of ospreys (Pandion haliaetus) nesting in Chesapeake Bay regions of concern. Arch. Environ. Contam. Toxicol. 47:126-140.

Rattner, B. A., P. C. McGowan, J. S. Hatfield, C.-S. Hong, and S. G. Chu. 2001. Organochlorine contaminant exposure and reproductive success of black-crowned night herons (Nycticorax nycticorax) nesting in Baltimore Harbor, Maryland. Arch. Environ. Contam. Toxicol. 41:73-82.

Rattner, B. A., et al. 2006. Toxicity and hazard of vanadium to mallard ducks (Anas platyrhynchos) and Canada geese (Branta canadensis). J. Toxicol. Environ. Health A 69:331-351.

Rattner, B. A., et al. 1993. Biomonitoring environmental contamination in pipping black-crowned night heron embryos: induction of cytochrome P450. Eviron. Toxicol. Chem. 12:1719-1732.

Rattner, B. A., M. J. Melancon, C. P. Rice, W. Riley Jr., J. Eisemann, and R. K. Hines. 1997. Cytochrome P450 and organochlorine contaminants in black-crowned night-herons from the Chesapeake Bay Region, USA. Eviron. Toxicol. Chem. 16:2315-2322.

Rattner, B. A., et al. 2008. Apparent tolerance of turkey vultures (Cathartes aura) to the non-steroidal antiinflammatory drug diclofenac. Environ. Toxicol. Chem. 27:2341-2345.

Risebrough, R. W., P. Rieche, D. W. Peakall, S. G. Herman, and M. N. Kirven. 1968. Polychlorinated biphenyls in the global ecosystem. Nature 220:1098-1102.

Robbins, C. S., and R. E. Stewart. 1949. Effects of DDT on bird population of scrub forest. J. Wildl. Manage. 13:11-16.

Roberts, D., R. Tren, R. Bate, and J. Zambone. 2010. The excellent powder DDT's political and scientific history. Indianapolis, IN. Dog Ear Publishing, 432 pp.

Rosene, W. Jr. 1965. Effects of field application of heptachlor on bobwhite quail and other wild animals. J. Wildl. Manage. 29:554-580.

Ryckman, D. P., et al. 1998. Spatial and temporal trends in organochlorine contamination and bill deformities in double-crested cormorants (Phalacrocorax auritus) from the Canadian Great Lakes. Environ. Monit. Assess. 53:169-195.

Safe, S. 1984. Polychlorinated biphenyls (PCBs) and polybrominated biphenyls (PBBs): biochemistry, toxicology, and mechanism of action. Crit. Rev. Toxicol. 13:319-393.

Safe, S. 1990. Polychlorinated biphenyls (PCBs), dibenzo-p-dioxins (PCDDs), dibenzofurans (PCDFs), and related compounds: environmental and mechanistic considerations which support the development of toxic equivalency factors (TEFs). Crit. Rev. Toxicol. 21:51-58.

Sagerup, K., E. O. Henriksen, J. U. Skaare, and G. W. Gabrielsen. 2002. Intraspecific variation in trophic feeding levels and organochlorine concentrations in glaucous gulls (Larus hyperboreus) from Bjørnøya, the Barents Sea. Ecotoxicology 11:119-125.

Sagerup, K., E. O. Henriksen, A. Skorping, J. U. Skaare, and G. W. Gabrielsen. 2000. Intensity of parasitic nematodes increases with organochlorine levels in the glaucous gull. J. Appl. Ecol. 37:532-539.

Saita, E., S. Hayama, H. Kajigaya, K. Yoneda, G. Watanabe, and K. Taya. 2004. Histologic changes in thyroid glands from great cormorant (Phalacrocorax carbo) in Tokyo Bay, Japan: possible association with environmental contaminants. J. Wildl. Dis. 40:763-768.

Sample, B. E., and G. W. Suter. 1999. Ecological risk assessment in a large river-reservoir: 4. Piscivorous wildlife. Environ. Toxicol. Chem. 18:610-620. 
Sanderson, J. T., and G. D. Bellward. 1995. Hepatic microsomal ethoxyresorufin $O$-deethylase-inducing potency in ovo and cytosolic Ah receptor binding affinity of 2,3,7,8-tetrachlorodibenzo- $p$-dioxin: comparison of four avian species. Toxicol. Appl. Pharmacol. 132:131-145.

Sanderson, J. T., J. E. Elliott, R. J. Norstrom, P. E. Whitehead, L. E. Hart, K. M. Cheng, and G. D. Bellward. 1994a. Monitoring biological effects of polychlorinated dibenzo-p-dioxins, dibenzofurans and biphenyls in great blue heron chicks. J. Toxicol. Environ. Health 41:435-450.

Sanderson, J. T., R. J. Norstrom, J. E. Elliott, L. E. Hart, K. M. Cheng, and G. D. Bellward. 1994b. Biological effects of polychlorinated dibenzo- $p$-dioxins, dibenzofurans, and biphenyls in double-crested cormorant chicks (Phalacrocorax auritus). J. Toxicol. Environ. Health 41:247-265.

Schafer, E. W. Jr., W. A. Bowles Jr., and J. Hurlbut. 1983. The acute oral toxicity, repellency, and hazard potential of 998 chemicals to one or more species of wild and domestic birds. Arch. Environ. Contam. Toxicol. 12:355-382.

Scheuhammer, A. M. 1987. The chronic toxicity of aluminum, cadmium, mercury, and lead in birds: a review. Environ. Pollut. 46:263-295.

Scheuhammer, A. M. 1991. Effects of acidification on the availability of toxic metals and calcium to wild birds and mammals. Environ. Pollut. 71:329-375.

Scheuhammer, A. M., and P. J. Blancher. 1994. Potential risk to common loons (Gavia immer) from methylmercury exposure in acidified lakes. Hydrobiologia 278/280:445-455.

Scheuhammer, A. M., C. M. Atchison, A. H. K. Wong, and D. C. Evers. 1998b. Mercury exposure in breeding common loons (Gavia immer) in central Ontario, Canada. Environ. Toxicol. Chem. 17:191-196.

Scheuhammer, A. M., et al. 2008. Relationships among mercury, selenium, and neurochemical parameters in common loons (Gavia immer) and bald eagles (Haliaeetus leucocephalus). Ecotoxicology 17:93-101.

Scheuhammer, A. M., M. W Meyer, M. B. Sandheinrich, and M. W. Murray. 2007. Effects of environmental methylmercury on the health of wild birds, mammals, and fish. Ambio 36:12-19.

Scheuhammer, A. M., J.A. Perrault, and D. E. Bond. 2001. Mercury, methylmercury, and selenium concentrations in eggs of common loons (Gavia immer) from Canada. Environ. Monit. Assess. 72:79-94.

Scheuhammer, A. M., A. H. K. Wong, and D. E. Bond. 1998a. Mercury and selenium accumulation in common loons (Gavia immer) and common mergansers (Mergus merganser) from eastern Canada. Environ. Toxicol. Chem. 17:197-201.

Scott, T. G., Y. L. Willis, and J. A. Ellis 1959. Some effects of a field application of dieldrin on wildlife. J. Wildl. Manage. 23:409-427.

Sheail, J. 1985. Pesticides and nation conservation: The British experience, 1950-1975. Oxford: Clarendon Press, 276 pp.

Shear, H., N. Stadler-Salt, P. Bertram, and P. Horvatin. 2003. The development and implementation of indicators of ecosystem health in the Great Lakes basin. Environ. Monit. Assess. 88:119-152.

Shultz, S., et al. 2004. Diclofenac poisoning is widespread in declining vulture populations across the Indian subcontinent. Proc. Royal Soc. Lond. B 271(Suppl.):S458-S460.

Sileo, L., L. Karstad, R. Frank, M. V. H. Holdrinet, E. Addison, and H. E. Braun. 1977. Organochlorine poisoning of ring-billed gulls in southern Ontario. J. Wildl. Dis. 3:313-322.

Skorupa, J. P. 1998a. Selenium poisoning of fish and wildlife in nature: lessons from twelve real world experiences. In Environmental chemistry of selenium, eds. W. T. Frankenberger, Jr. and R. A. Engberg, pp. 315-354. New York, NY: Marcel Dekker.

Skorupa, J. P. 1998b. Risk assessment for the biota database of the National Irrigation Water Quality Program. Prepared for the National Irrigation Water Quality Program, U.S. Department of the Interior, Washington, DC.

Smith, T. G., and F. A. J. Armstrong. 1975. Mercury in seals, terrestrial carnivores, and principal food items of the Inuit from Holman, N. W. T. J. Fish. Res. Board Can. 32:795-801.

Smits, J. E., K. J. Fernie, G. R. Bortolotti, and T. A. Marchant. 2002. Thyroid hormone suppression and cellmediated immunomodulation in American kestrels (Falco sparverius) exposed to PCBs. Arch. Environ. Contam. Toxicol. 43:338-344.

Spalding, M. G., et al. 2000. Histologic, neurologic, and immunologic effects of methylmercury in captive great egrets. J. Wildl. Dis. 36:423-435.

Sparling, D. W., G. Linder, and C. A. Bishop. 2000. Ecotoxicology of amphibians and reptiles. Pensacola, FL: SETAC Press, 877 pp.

Spear, P. A., D. H. Bourbonnais, R. J. Norstrom, and T. W. Moon. 1990. Yolk retinoids (vitamin A) in eggs of the herring gull and correlations with polychlorinated dibenzo-p-dioxins and dibenzofurans. Environ. Toxicol. Chem. 9:1053-1061. 
Spry, D. J., and J. G. Wiener. 1991. Metal bioavailability and toxicity to fish in low-alkalinity lakes: a critical review. Environ. Pollut. 71:243-304.

Stalling, D. L., R. J. Norstrom, L. M. Smith, and M. Simon. 1985. Patterns of PCDD, PCDF and PCB contamination in Great Lakes fish and birds and their characterization by principal components analysis. Chemosphere 14:627-643.

Stapleton, M., P. O. Dunn, J. McCarty, A. Secord, and L. A. Whittingham. 2001. Polychlorinated biphenyl contamination and minisatellite DNA mutation rates of tree swallows. Environ. Toxicol. Chem. 20:2263-2267.

Stickel, L. F., W. H. Stickel, and R. Christensen. 1966. Residues of DDT in brains and bodies of birds that died on dosage and in survivors. Science 151:1549-1551.

Stickel, L. F., W. H. Stickel, and J. W. Spann. 1969. Tissue residues of dieldrin in relation to mortality in birds and mammals. In Chemical fallout: Current research on persistent pesticides, eds. M. W. Miller and G. G. Berg, pp. 174-204, Springfield, IL: Charles C. Thomas.

Stickel, L. F., S. N. Wiemeyer, and L. J. Blus. 1973. Pesticide residues in eggs of wild birds: adjustment for loss of moisture and lipid. Bull. Environ. Contam. Toxicol. 9:193-196.

Stickel, W. H., L. F. Stickel, and F. B. Coon. 1970. DDE and DDD residues correlated with mortality of experimental birds. In Pesticide symposia, ed. W. P. Deichmann, pp. 287-294. Miami, FL: Helios and Associates.

Stickel, W. H., L. F. Stickel, R. A. Dyrland, and D. L. Hughes. 1984. Aroclor 1254® residues in birds: lethal levels and loss rates. Arch. Environ. Contam. Toxicol. 13:7-13.

Stone, W. B., J. C. Okoniewski, and J. R. Stedelin. 1999. Poisoning of wildlife with anticoagulant rodenticides in New York. J. Wildl. Dis. 35:187-193.

Stone, W. B., J. C. Okoniewski, and J. R. Stedelin. 2003. Anticoagulant rodenticides and raptors: recent findings from New York, 1998-2001. Bull. Environ. Cont. Toxicol. 70:34-40.

Strause, K. D., et al. 2007a. Plasma to egg conversion factor for evaluating polychlorinated biphenyl and DDT exposures in great horned owls and bald eagles. Environ. Toxicol. Chem. 26:1399-1409.

Strause, K. D., et al. 2007b. Risk assessment of great horned owls (Bubo virginianus) exposed to polychlorinated biphenyls and DDT along the Kalamazoo River, Michigan, USA. Environ. Toxicol. Chem. 26:1386-1398.

Strong, L. 1938. Insect and pest control in relation to wildlife. Trans 3rd N. Am. Wildl. Conf., American Wildlife Institute, Washington, DC, USA, pp. 543-547.

Struger, J., and D. V. Weseloh. 1985. Great Lakes caspian terns: egg contaminants and biological implications. Col. Waterbirds 8:142-149.

Swan, G. E., et al. 2006. Toxicity of diclofenac to Gyps vultures. Biol. Letters 2:279-282.

Tejning, S. 1967. Biological effects of methyl mercury dicyandiamide-treated grain in the domestic fowl Gallus gallus L. Oikos (Suppl 8):116.

Thiel, D. A., S. G. Martin, J. W. Duncan, M. J. Lemke, W. R. Lance, and R. E. Peterson. 1988. Evaluation of the effects of dioxin-contaminated sludges on wild birds. In: Proceedings of the 1988 Technical Association of Pulp and Paper Environmental Conference, Charleston, SC, pp. 145-148.

Thompson, D. R. 1996. Mercury in birds and terrestrial mammals. In Environmental contaminants in wildlife: Interpreting tissue concentration, eds. W. N. Beyer, G. H. Heinz, and A. W. Redmond-Norwood, pp. 341-356. Boca Raton, FL: Lewis Publishers Inc.

Thompson, D. R., and R. W. Furness. 1989. The chemical form of mercury stored in South Atlantic seabirds. Environ. Pollut. 60:305-317.

Tillitt, D. E., et al. 1992. Polychlorinated biphenyl residues and egg mortality in double-crested cormorants from the Great Lakes. Environ. Toxicol. Chem. 11:1281-1288.

Toschik, P. C., et al. 2005. Effects of contaminant exposure on reproductive success of ospreys (Pandion haliaetus) nesting in Delaware River and Bay, USA. Environ. Toxicol. Chem. 24:617-628.

[USACHPPM] US Army Center for Health Promotion and Preventive Medicine. 2000. Standard practice for wildlife toxicity reference values. Technical Guide No. 254. http://usaphcapps.amedd.army.mil/erawg/ tox/tg254(Oct00final).pdf

[U.S. EPA] U.S. Environmental Protection Agency. 1995. Final water quality guidance for the Great Lakes system; final rule. Federal Register 60:15366-15425.

[U.S. EPA] U.S. Environmental Protection Agency. 2008. Final risk mitigation decision for ten rodenticides. http://www.epa.gov/pesticides/reregistration/rodenticides/finalriskdecision.htm (accessed June 20, 2008).

Van den Berg, M., et al. 1998. Toxic equivalency factors (TEFs) for PCBs, PCDDs, PCDFs for humans and wildlife. Environ. Health Perspect. 106:775-792. 
Van Velzen, A. C., W. B. Stiles, and L. F. Stickel. 1972. Lethal mobilization of DDT by cowbirds. J. Wildl. Manage. 36:733-739.

Verreault, J., R. J. Letcher, E. Ropstad, E. Dahl, and G. W. Gabrielsen. 2006b. Organohalogen contaminants and reproductive hormones in incubating glaucous gulls (Larus hyperboreus) from the Norwegian Arctic. Environ. Toxicol. Chem. 25:2990-2996.

Verreault, J., S. Shahmiri, G. W. Gabrielsen, and R. J. Letcher. 2007. Organohalogen and metabolicallyderived contaminants and associations with whole body constituents in Norwegian Arctic glaucous gulls. Environ. Internat. 33:823-830.

Verreault, J., R. A. Villa, G. W. Gabrielsen, J. U. Skaare, and R. J. Letcher. 2006a. Maternal transfer of organohalogen contaminants and metabolites to eggs of Arctic-breeding glaucous gulls. Environ. Pollut. 144:1053-1060.

Verrett, M. J. 1970. Effects of 2,4,-T on man and the environment. In: Hearings before the Subcommittee on Energy, Natural Resources and the Environment of the Committee on Commerce, US Senate, Serial 91-60. US Government Printing Office, Washington DC.

Wasserman, M., D. Wasserman, S. Cucos, and H. J. Miller. 1979. World PCBs map: storage and effects in man and his biologic environment in the 1970's. Ann. N. Y. Acad. Sci. 320:69-124.

Wax, P. M. 2006. Historical principles and perspectives. In Goldfrank's toxicological emergencies, 8th edition, eds. L.R. Goldfrank, N. Flomenbaum, R.S. Hoffman, M. A., N. A. Lewin, and L. S. Nelson, pp. 1-17. New York, NY: McGraw-Hill.

Wayland, M., S. Trudeau, T. Marchant, D. Parker, and K. A. Hobson. 1998. The effect of pulp and paper mill effluent on an insectivorous bird, the tree swallow. Ecotoxicology 7:237-251.

Weech, S. A., A. M. Scheuhammer, J. E. Elliott, and K. M. Cheng. 2004. Mercury in fish from the Pinchi Lake region, British Columbia, Canada. Environ. Pollut. 131:275-286.

Weech, S. A., A. M. Scheuhammer, and J. E. Elliott. 2006. Mercury exposure and reproduction in fisheating birds breeding in the Pinchi Lake region, British Columbia, Canada. Environ. Toxicol. Chem. 25:1433-1440.

Wetmore, A. 1919. Lead poisoning in waterfowl. U.S. Department of Agriculture, Bulletin 793, 12 pp.

White, D. H., and J. T. Seginak. 1994. Dioxins and furans linked to reproductive impairment in wood ducks. J. Wildl. Manage. 58:100-106.

Whitehead, F. E. 1934. The effect of arsenic, as used in poisoning grasshoppers, upon birds. Oklahoma Agricultural and Mechanical College Agriculture Experiment Station. Experiment Station Bulletin Number 218, $54 \mathrm{pp}$.

Wiemeyer, S. N. 1996. Other organochlorine pesticides in birds. In: Environmental contaminants in wildlife: interpreting tissue concentrations, eds. W. N. Beyer, G. H. Heinz, and A. W. Redmon-Norwood, pp. 99-115. SETAC Special Publication Series. Boca Raton, FL: Lewis Publishing Inc.

Wiemeyer, S. N., C. M. Bunck, and C. J. Stafford. 1993. Environmental contaminants in bald eagle eggs-1980 -1984 - and further interpretations of relationships to productivity and shell thickness. Arch. Environ. Contam. Toxicol. 24:213-227.

Wiener, J. G., D. P. Krabbenhoft, G. H. Heinz, and A. M. Scheuhammer. 2003. Ecotoxicology of mercury. In Handbook of Ecotoxicology, 2nd edition, eds. Hoffman, D. J., B. A. Rattner, G. A. Burton, and J. Cairns, pp. 409-463. Boca Raton, FL, CRC Press.

Wigglesworth, V. B. 1945. DDT and the balance of nature. The Atlantic Monthly 176:107-113.

Williams, L. L., J. P. Giesy, D. A. Verbrugge, S. Jurzysta, and K. Stromborg. 1995. Polychlorinated biphenyls and 2,3,7,8-tetrachlorodibenzo- $p$-dioxin equivalents in eggs of double-crested cormorants from a colony near Green Bay, Wisconsin, USA Arch. Environ. Contam. Toxicol. 29:327-333.

Wobeser, G., and M. Swift. 1976. Mercury poisoning in a wild mink. J. Wildl. Dis. 12:335-340.

Wobeser, G., N. O. Nielsen, and B. Schiefer. 1976. Mercury and mink. II. Experimental methyl mercury intoxication. Can. J. Comp. Med. 40:34-45.

Wolfe, M. F., S. Schwarzbach, and R. A. Sulaiman. 1998. The effects of mercury on wildlife: A comprehensive review. Environ. Toxicol. Chem. 17:146-160.

Wolfe, M. F., et al. 2007. Wildlife Indicators. In Ecosystem response to mercury contamination: indicators of change, eds. R. Harris, D. P. Krabbenhoft, R. Mason, M. W. Murray, R. Reash and T. Saltman, pp. 123-189. Webster, New York, NY: CRC Press.

Woodford, J. E., W. H. Karasov, M. W. Meyer, and L. Chambers. 1998. Impact of 2,3,7,8-TCDD exposure on survival, growth, and behaviour of ospreys breeding in Wisconsin, USA. Environ. Toxicol. Chem. 17:1323-1331.

Wootton, J. C., and J. C. Alexander. 1959. Some chemical characteristics of the chicken edema disease factor. J Assoc Offic Agr Chem 42:141-148. 
Wren, C. D. 1985. Probable case of mercury poisoning in a wild otter, Lutra canadensis, in northwestern Ontario. Can. Field Nat. 99:112-114.

Wren, C. D. 1986. A review of metal accumulation and toxicity in wild mammals. I. Mercury. Environ. Res. 40:210-244.

Wren, C. D., D. B. Hunter, J. F. Leatherland, and P. M. Stokes. 1987a. The effects of polychlorinated biphenyls and methylmercury, singly and in combination, on mink. I: Uptake and toxic responses. Arch. Environ. Contam. Toxicol 16:441-447.

Wren, C. D., D. B. Hunter, J. F. Leatherland, and P. M. Stokes. 1987b. The effects of polychlorinated biphenyls and methylmercury, singly and in combination on mink. II. Reproduction and kit development. Arch. Environ. Contam. Toxicol. 16:449-454.

Wren, C. D., P. M. Stokes, and K. L. Fischer. 1986. Mercury levels in Ontario mink and otter relative to food levels and environmental acidification. Can. J. Zool. 64:2854-2859.

Wurster, D. H., C. J. Wurster Jr., and W. N. Strickland. 1965. Bird mortality following DDT spray for Dutch elm disease. Ecology 46:488-499.

Yasui, T., et al. 2007. Functional characterization and evolutionary history of two aryl hydrocarbon receptor isoforms (AhR1 and AhR2) from avian species. Toxicol. Sci. 99:101-117. 
$\because$ Taylor \& Francis

Taylor \& Francis Group

http://taylorandfrancis.com 


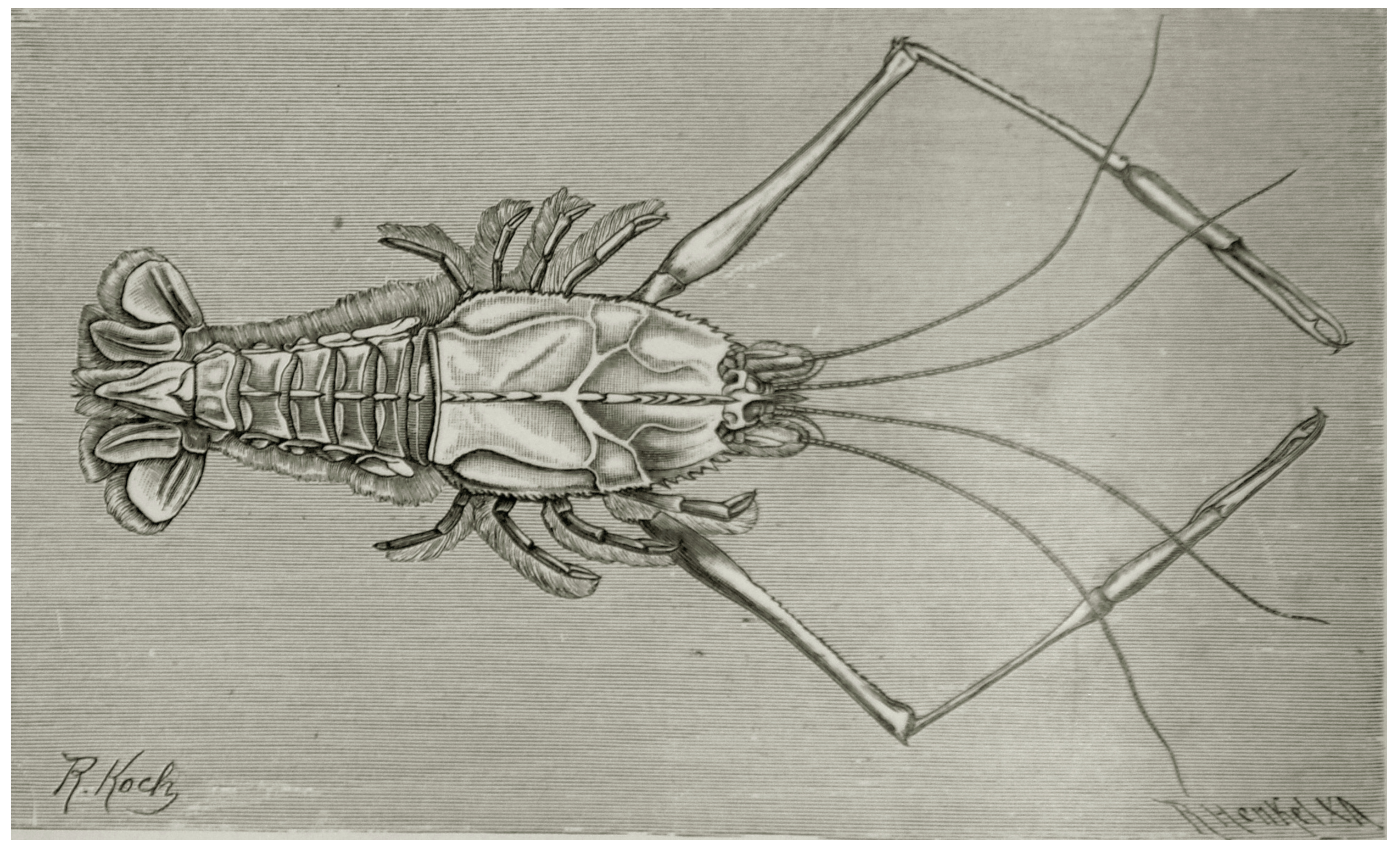

\section{Slender-clawed crayfish}

By R. Koch, from The Royal Natural History, edited by Richard Lydekker, Frederick Warne \& Co., London, 1893-94. 